SEB A S T I A N EDW ARDS

University of California, Los Angeles

\title{
Is the U.S. Current Account Deficit Sustainable? If Not, How Costly Is Adjustment Likely to Be?
}

MANY ANALYSTS IN academia, the private sector, and applied research institutions express increasing concern about the growing U.S. current account deficit. There is a general sense that current global imbalances are unsustainable and that adjustment must come sooner rather than later. The unprecedented magnitude of the U.S. current account deficit and the United States' growing net foreign indebtedness have fueled these worries, with many analysts arguing that, unless something is done, the world will move toward a major financial crisis. ${ }^{1}$ Some have gone as far as to suggest an imminent collapse of the dollar and a global financial meltdown. ${ }^{2}$ Underlying this view is the fact that, if the deficit continues at its current level, U.S. net international liabilities will eventually reach 100 percent of GDP, a figure widely considered to be excessively large. ${ }^{3}$

The source of financing of the U.S. current account deficit has also become a matter of concern. A number of authors have argued that, by relying on foreign and particularly Asian central banks' purchases of

1. Although most of these alarmist discussions have taken the form of newspaper opinion pieces, there have also been a few policy papers on the subject. See, for example, Roubini and Setser (2004).

2. See, for example, Roubini and Setser (2004). For an excellent set of papers on the subject, see Bergsten and Williamson (2004).

3. For example, in a very clear discussion of this issue, Michael Mussa said, "[T]here probably is a practical upper limit for US net external liabilities at something less than 100 percent of US GDP and, accordingly ... . current account deficits of 5 percent or more of US GDP are not indefinitely sustainable" (Mussa, 2004, p. 114). 
Treasury securities, the United States has become extremely vulnerable to sudden changes in expectations and economic sentiments. ${ }^{4}$

Robert Skidelsky recently argued in the New York Times that the value of the dollar is one of the most important sources of political tension between the United States and Europe. Arguing that "[U]nilateralism is not more acceptable in currency matters than in foreign policy," Skidelsky points out that,

The United States is the only major country proclaiming itself indifferent to its currency's value. In countries running persistent current account deficits, governments normally — indeed must-reduce domestic consumption. But so far, the United States has relied on other countries to adjust their economies to profligate American spending. ... .

There is, however, an alternative view. Some authors have argued that, in an era of increasing financial globalization and rapid U.S. productivity gains, it is possible — indeed, even logical and desirable-for the United States to run very large current account deficits for a very long period (say, a quarter of a century). In this view, growing international portfolio diversification implies that the rest of the world will be willing to accumulate large U.S. liabilities during the next few years, maybe even in excess of 100 percent of U.S. GDP. From this perspective, since the U.S. current account deficit poses no threat, there are no fundamental reasons to justify a significant fall in the value of the dollar. ${ }^{6}$

This paper analyzes the relationship between the dollar and the U.S. current account, with particular attention to the issue of sustainability and the mechanics of current account adjustment. I develop a portfolio model of the current account and show that, even under a very positive scenario where foreigners' (net) demand for U.S. assets doubles from its current level, the U.S. current account will have to go through a significant adjustment in the not-too-distant future. Indeed, one cannot rule out a scenario where the U.S. current account deficit shrinks abruptly by 3 to 6 percent of GDP. To get an idea of the possible consequences of such an adjustment, I also analyze the international historical evidence

4. See, for example, Martin Wolf's article in the Financial Times, "Funding America's Recovery is a Very Dangerous Game," October 1, 2003, p. 15.

5. "Winning Back Europe's Heart: Rogue Dollar," New York Times, February 20, 2005, p. 9.

6. Dooley, Folkerts-Landau, and Garber (2004a, 2004b); see also Cooper (2004) and Caballero, Farhi, and Hammour (2004). 
on current account reversals. The results of this empirical investigation indicate that significant current account reversals have tended to result in large declines in GDP growth.

\section{The U.S. Dollar and the Current Account: A Thirty-Year Perspective}

This section analyzes the behavior of the U.S. real exchange rate (RER) and current account since the adoption of floating exchange rates in the early 1970s. ${ }^{7}$ I begin by discussing the course of the U.S. RER and current account during that period and the changing nature of the U.S. trade-weighted RER index. I argue that the last thirty years of U.S. RER behavior can be divided into six distinct phases. Second, I discuss the most recent data on the U.S. current account, including its sources of financing. And third, I provide some international evidence on current account imbalances during the last three decades. This comparative analysis helps in placing the recent U.S. experience in historical context.

\section{Six Phases of Real Exchange Rate Behavior}

Figure 1 presents quarterly data for the U.S. current account balance as a percentage of GDP and for the Federal Reserve's trade-weighted index of the U.S. RER, both for the period 1973-2004; in this figure, as in the rest of the paper, the RER index is defined such that an increase represents a real appreciation. The figure shows that current account deficits have become increasingly large since 1992. It also shows that, over the first decade of floating exchange rates (1973-82), the United States ran small current account surpluses or deficits, which averaged to a small surplus of 0.04 percent of GDP. In contrast, over 1983-2004 the current account balance was in deficit, on average, by 2.4 percent of GDP. Figure 1 also

7. Because of space considerations, I do not discuss in detail some important issues such as the stationarity of the RER and its (changing) volatility through time. Most recent analyses based on panel data have found that the RER is stationary and that its half-life cycle is less than the three to five years traditionally considered to be the consensus view. See Choi, Mark, and Sul (2004). An analysis of U.S. RER volatility indicates that for the complete period 1975-2004 the U.S. RER index exhibited one of the highest volatilities in the sample. Only the British pound, the Japanese yen, and the euro had greater volatility. Within this period, the RER volatility of the U.S. dollar was at its highest in 1985-89, which roughly corresponds to phase III (a period of rapid depreciation) in figure 2. 
Figure 1. Real Exchange Rate and Current Account Balance, 1973-2004

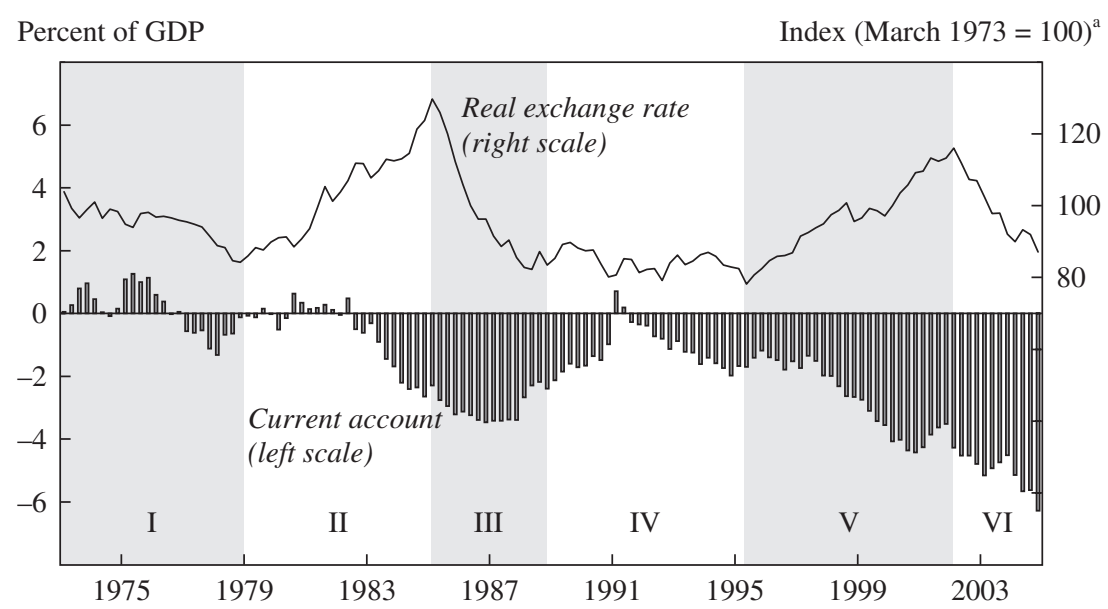

Source: Bureau of Economic Analysis, National Income and Product Accounts, International Transactions Accounts; Federal Reserve data.

a. Price-adjusted Major Currencies index.

shows that during the whole period under consideration the RER index fluctuated within a wide range: from 91.2 at its lowest point, it rose to 136.3 at its highest, with a mean for the period of 105.3. Finally, the figure demonstrates an apparent negative correlation between the tradeweighted real value of the dollar and the current account balance: periods of a strong dollar have tended to coincide with periods of larger current account deficits. Although the relationship is not exact, the synchronicity between the two variables is quite high: the contemporaneous coefficient of correlation between the logarithm of the RER index and the current account balance is -0.53 ; the highest value for the correlation coefficient $(-0.60)$ is obtained when the log of the RER is lagged three quarters.

Recent policy debates about the value of the dollar illustrate the massive changes that have occurred in U.S. trade relations during the last three decades. Discussions of the dollar in the early 1970s dealt almost exclusively with bilateral exchange rates—both nominal and real—between the dollar and the currencies of other industrial countries; more recently the debate has increasingly focused on the dollar's value in terms of the currencies of emerging economies, including the Chinese renminbi, the Korean won, and the Malaysian ringgit. During the last few years the Mexican peso has also become an important determinant of the trade- 
weighted value of the dollar; this was not the case when the Smithsonian Agreement was abandoned and the regime of floating exchange rates began in 1973. Between 1995 and 2005 the renminbi's weight in the Federal Reserve trade-weighted RER index of the dollar rose from 5.7 percent to 11.4 percent, and the Mexican peso's from 7.0 percent to 10.0 percent. Meanwhile the yen's weight declined from 16.5 percent to 10.6 percent. In fact, the trade-weighted RER of the dollar is dominated today by the Asian nations, which (excluding India) have a combined weight in the index of 38.8 percent. The currencies of commodity-exporting countries, as a group, are also very important, with a weight of 24.6 percent. Finally, the launching of the euro in 1999 has marginalized the British pound: although its weight of 5.2 percent is still quite respectable, the pound is no longer among the top five currencies in the index. The situation was quite different in 1998, when the pound had a higher weight than the currencies of all but one of the countries that would eventually adopt the euro: in that year the deutsche mark had a weight of 6.4 percent, and the pound a weight of 5.9 percent. $^{8}$

One can distinguish in figure 1 six distinct phases in U.S. RER behavior for the thirty-two-year period 1973-2004. A summary of these six phases is also in large measure a summary of the history of the international financial system since the inception of floating: ${ }^{9}$

-Phase I, 1973:1-1978:4. The early years of floating were characterized by a depreciating trend for the dollar in real terms, with the decline in value cumulating to 18.1 percent over the twenty-four quarters. During this period the standard deviation of monthly log differences of the RER index was 0.0205. During the early part of this phase (1973-76), the current account was in surplus, but this turned into a small deficit in 1977 and 1978.

-Phase II, 1979:1-1985:1. During the next twenty-five quarters the dollar experienced a 49.3 percent appreciation in real terms. Meanwhile the current account went into deficit, which reached 2.9 percent of U.S. GDP in 1984:4. The standard deviation of monthly log differences of the RER index was 0.022 , slightly higher than in phase I. In view of the dollar's strengthening and the related increase in the U.S. current account deficit, on

8. In 2005 the euro has a weight of 18.8 percent in the Federal Reserve index; in 1995 the currencies that the euro later replaced had a combined weight of 17.3 percent.

9. Figure 1 presents the Federal Reserve's broad RER index. The same six phases are also apparent when alternative indexes are used. 
September 22, 1985, the members of the Group of Five major industrial countries (the G-5: the United States, Japan, the United Kingdom, France, and Germany) agreed to implement concerted and coordinated interventions in the foreign exchange market. As part of this agreement, which came to be known as the Plaza Agreement, the G-5 countries also committed themselves to put in place coordinated macroeconomic policies that would reduce the costs of the global adjustment process.

-Phase III, 1985:2-1988:4. During the period following the Plaza Agreement, the dollar experienced a rapidly depreciating trend, with a peakto-trough change in the index of -28.7 percent. RER volatility increased substantially during these fifteen quarters: the standard deviation of monthly log differences of the RER index was 0.0268. The current account deficit continued to grow, however, until in mid-1987 it stabilized at around 3.6 percent of U.S. GDP. From that point onward the current account began to improve, and by 1988:4 the deficit had declined to 2.4 percent of GDP. On February 22, 1987, the ministers of finance and central bank governors of the G-6 (the former G-5 plus Canada) released a communiqué, which came to be known as the Louvre Accord, declaring that significant progress had been made in achieving global adjustment, and that "Further substantial exchange rate shifts among their currencies could damage growth and adjustment prospects in [the G-6] countries." The communiqué went on to say that the G-6 "agreed to cooperate closely to foster stability of exchange rates around current levels." 10

-Phase IV, 1989:1-1995:2. During the next phase the dollar continued to depreciate in real terms, but at a much lower rate than in the preceding phase: during these twenty-six quarters the total real depreciation was 10 percent. The standard deviation of monthly log differences of the RER index over this period was 0.0232, and the current account balance continued to improve, until in 1991:1 the United States posted its first current account surplus in many years. The current account balance averaged -1.15 percent of U.S. GDP during this phase.

-Phase V, 1995:3-2002:1. This phase was characterized by a troughto-peak real dollar appreciation of 33.4 percent (although, as figure 1 shows, between 1998:1 and 1999:4 there was a short-lived period of real depreciation). Interestingly, during this phase RER volatility declined significantly: the standard deviation of monthly log differences of the RER

10. Quoted from the text of the Louvre communiqué, available at www.g8.utoronto. ca/finance/fm870222.htm. 
index was 0.0196 . This phase was also characterized by an increasing current account deficit: whereas in late 1995 and early 1996 the deficit was on the order of 1.5 percent of U.S. GDP, by early 2002 it was hovering just below 4 percent of GDP. In 1999, for the first time in many years, the U.S. federal government posted a budget surplus.

-Phase VI, 2002:2-2004:4. In the most recent (and continuing) phase, the real value of the dollar has accumulated a 14 percent real depreciation. The current account deficit has continued to widen, exceeding 5 percent of U.S. GDP toward the end of the sample. RER volatility has increased slightly: the standard deviation of log differences of the RER index was 0.0212. Other important macroeconomic developments during this phase included a worsening of the U.S. fiscal position and stiff increases in the prices of oil and other commodities.

Figure 2 breaks down the U.S. current account balance for 1973 through 2004 into its main components: the balance of trade in goods and services, the balance of trade in nonfinancial services, the income account, and transfers, all as percentages of GDP on a yearly basis. As the top left panel shows, large and persistent trade surpluses preceded the era of large current account deficits: already in the late 1970s the trade account was negative, and since mid-1976 it has had only one surplus quarter (1992:2). ${ }^{11}$ The top right panel shows that since 1996 the trade surplus in nonfinancial services has declined steadily, so that by 2004 it was only 0.3 percent of GDP. The income account remains positive, as the bottom left panel of the figure shows. The surplus has declined sharply since 1980, but given that for many years now the U.S. international investment position has been negative - that is, the United States has been a net debtor-the fact that the income account is still positive may seem surprising. The reason is that the return on U.S. assets held by foreigners has been systematically lower than the return on foreign assets in the hands of U.S. nationals. Finally, the bottom right panel shows that the transfers account has been negative in every year except one since 1946 . Recently the transfers deficit has been stable at approximately 0.7 percent of GDP.

\section{Recent Current Account Imbalances}

Table 1 presents data on the U.S. current account deficit and its financing for the period 1990-2004. The nature of external financing of the

11. Mann (2004) shows that most of the U.S. trade deficit is explained by deficits in automobiles and consumer goods. 

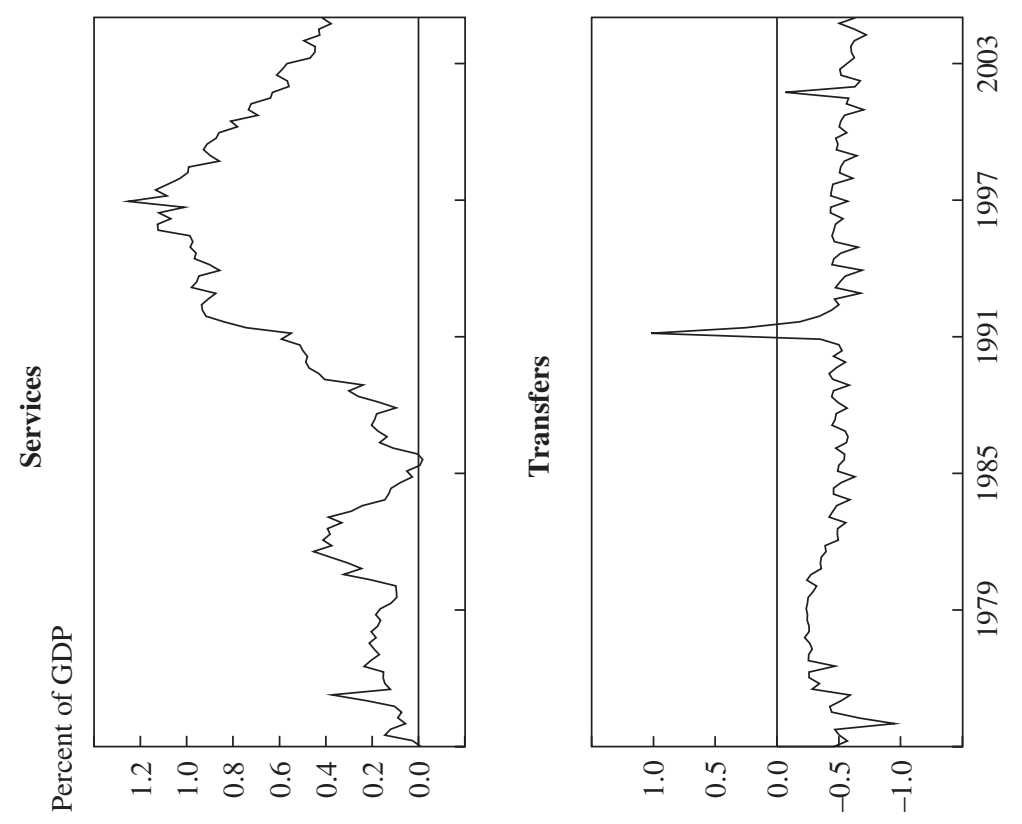

ปิ)
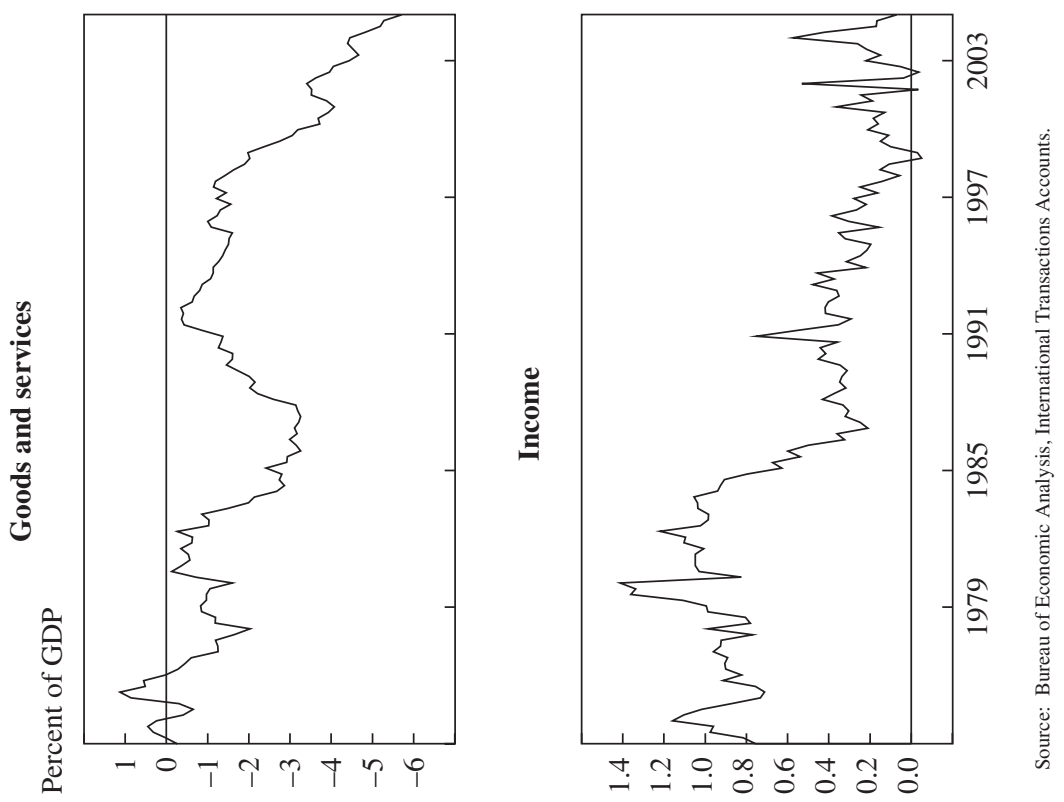


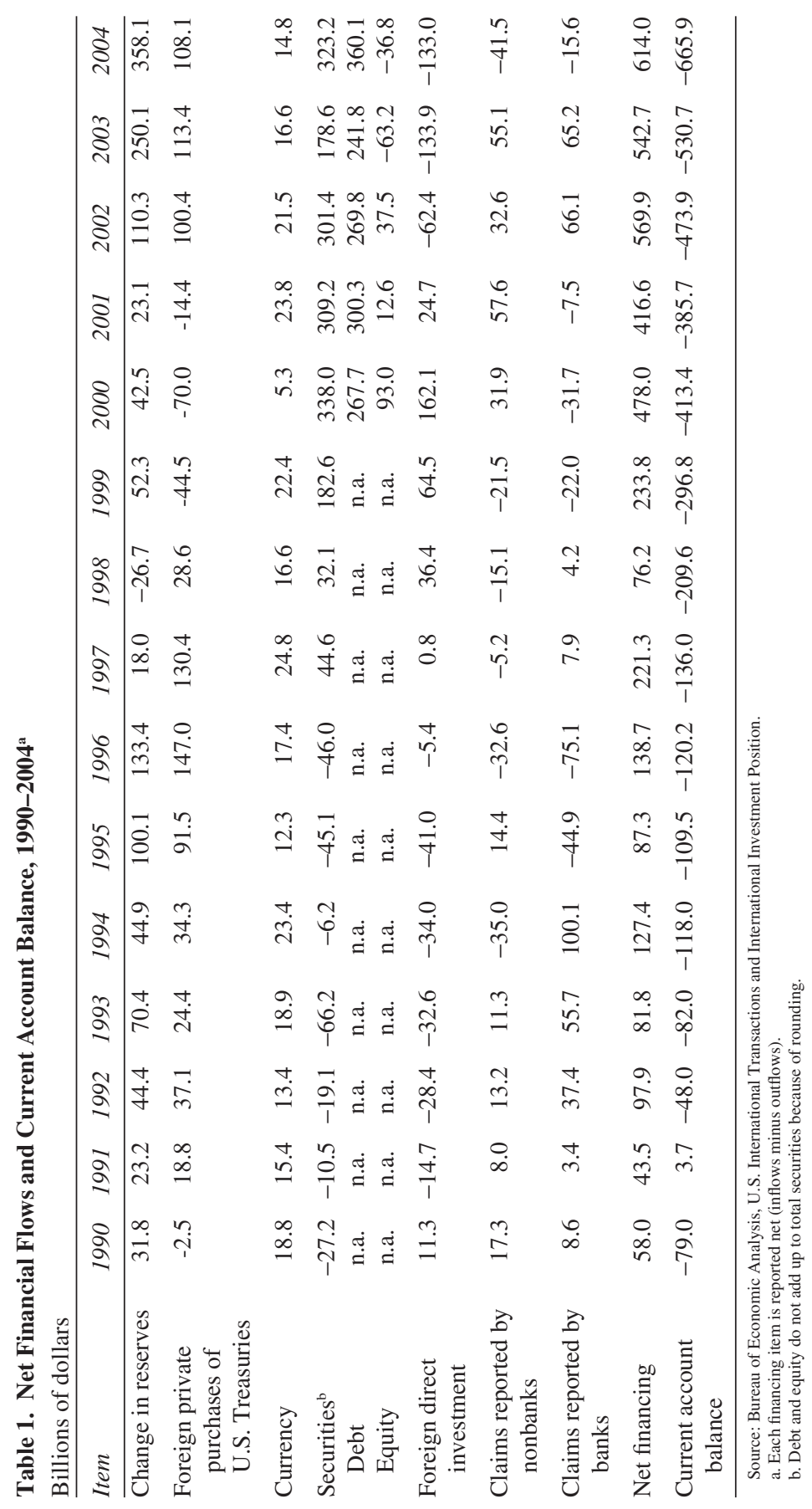


deficit has changed significantly in the last few years. Whereas from 1997 to 2000 inflows of foreign direct investment (FDI) contributed in an increasingly important way to financing the deficit, net FDI inflows fell sharply in 2001 and have been negative since then. Also, after four years (1999-2002) in which net equity flows were positive, these became negative in 2003-04. Table 1 also shows that during 2003 and 2004 the U.S. current account deficit was fully financed through net fixed-income flows (the sum of the first, second, and fifth rows in the table). Official foreign purchases of government securities-"Change in reserves" in table 1played a particularly important role in financing the 2003 and 2004 current account deficits. A number of analysts have argued that reliance on foreign central bank purchases of Treasury securities has made the United States particularly vulnerable to sudden changes in expectations and economic sentiments. ${ }^{12}$

Current account imbalances are reflected in changes in a country's net international investment position (NIIP): deficits result in a deterioration of the NIIP, and surpluses in an improvement. Figure 3 shows that the U.S. NIIP as a percentage of GDP has become increasingly negative since the mid-1980s: in 2004 U.S. net international liabilities reached 29 percent of GDP. An important feature of the U.S. NIIP that distinguishes it from those of most other countries is that gross international assets and gross international liabilities are held in different currencies. Whereas more than 70 percent of gross foreign assets held by U.S. nationals are denominated in foreign currency, approximately 95 percent of gross U.S. liabilities in the hands of foreigners are denominated in dollars. This means that U.S. net liabilities as a percentage of GDP are subject to "valuation effects" stemming from changes in the value of the dollar: a dollar depreciation reduces the value of U.S. net liabilities; as a result, the deterioration of the U.S. NIIP during 2002-04 was significantly smaller than the accumulated current account deficit during those two years (table 2).

A key question in current account sustainability analyses-discussed in detail below-is, What is the "reasonable" long-run equilibrium ratio of U.S. net international liabilities to GDP? The higher this ratio, the greater will be the sustainable current account deficit. According to some, the current ratio of almost 30 percent of GDP is already excessive;

12. See, for example, the article by Martin Wolf cited above. 
Figure 3. Net International Investment Position, 1976-2004a

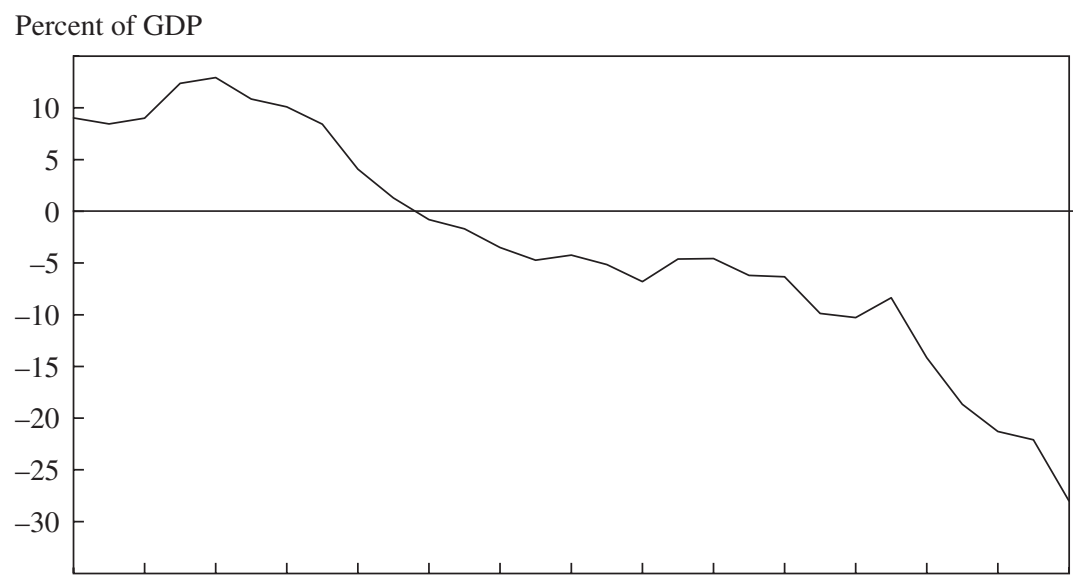

1978198019821984198619881990199219941996199820002002

Source: Bureau of Economic Analysis, National Income and Product Accounts, International Investment Position. a. Data for 2004 are author's projection. Direct investment positions are valued at current cost.

others believe that a NIIP-to-GDP ratio of up to 50 percent would be reasonable. ${ }^{13}$

One of the first things that undergraduate students of open-economy macroeconomics learn is that a country's current account is equal to the difference between its national saving and its domestic investment. Over the years a number of authors have argued that a worsening of a current account balance that stems from an increase in investment is very different from one that results from a decline in national saving. Some have gone as far as to argue that very large deficits in the current account "don't matter," as long as they are the result of increased (private sector) investment. ${ }^{14}$ As figure 4 shows, the recent deterioration of the U.S. current account has largely corresponded to a decline in national saving, and in particular of public and household saving, rather than a rise in investment. A simple implication of this trend-and one that is emphasized by most authors-is that an improvement in the U.S. current account will require not only an RER adjustment, but also an increase in the national saving rate to GDP. Symmetrically, a correction

13. See Obstfeld and Rogoff (2004) and Mussa (2004).

14. Corden (1994). 
Table 2. Net International Investment Position and Current Account Balance, 1998-2004

Billions of dollars

\begin{tabular}{lccccccc}
\hline Item & 1998 & 1999 & 2000 & 2001 & 2002 & 2003 & 2004 \\
\hline $\begin{array}{l}\text { Net international } \\
\text { liabilities } \\
\text { position }\end{array}$ & 900.0 & 775.5 & $1,388.7$ & $1,889.7$ & $2,233.0$ & $2,430.7$ & n.a. \\
$\begin{array}{c}\text { Change from } \\
\text { previous year }\end{array}$ & 79.3 & -124.5 & 613.3 & 500.9 & 343.3 & 197.7 & n.a. \\
$\begin{array}{c}\text { Current account } \\
\quad \text { deficit }\end{array}$ & 209.6 & 296.8 & 413.4 & 385.7 & 473.9 & 530.7 & 665.9 \\
$\begin{array}{l}\text { Valuation changes } \\
\text { a }\end{array}$ & -130.2 & -421.3 & 199.8 & 115.2 & -130.6 & -333.0 & n.a. \\
\hline
\end{tabular}

Source: Bureau of Economic Analysis, U.S. International Transactions and International Investment Position.

a. Current account deficit plus valuation changes equals change in net international investment position from previous year.

of current global imbalances will also require a decline in Europe's and Japan's saving rates, or an increase in their investment rates, or some combination of the two.

\section{The U.S. Current Account Deficit in International Perspective}

How large are the recent U.S. current account deficits from a comparative point of view? And how large is the U.S. net international liabilities position compared with those of other developed countries through history? The top panel of table 3 presents data on the distribution of current account balances (as a percentage of GDP) in the world economy, as well as in six country groups - the industrial countries, Latin America, Asia, the Middle East, Africa, and Eastern Europe-for 1971 through 2001 and 1984 through 2001. (The data are unweighted averages for each country.) At almost 6 percent of GDP, today's U.S. current account deficit is very large indeed from a historical and international perspective: it is in the top decile of all the deficits recorded by all industrial countries in the first thirty years of floating exchange rates.

Since 1971 the United States has been the only large industrial country that has run current account deficits in excess of 5 percent of GDP. This reflects the unique position of the United States in the international financial system: U.S. assets have been in high demand, allowing the United States to run large and persistent deficits. On the other hand, this fact also suggests that the United States is moving into uncharted waters. As Mau- 
Figure 4. Investment and Saving, 1970-2003 ${ }^{\mathrm{a}}$

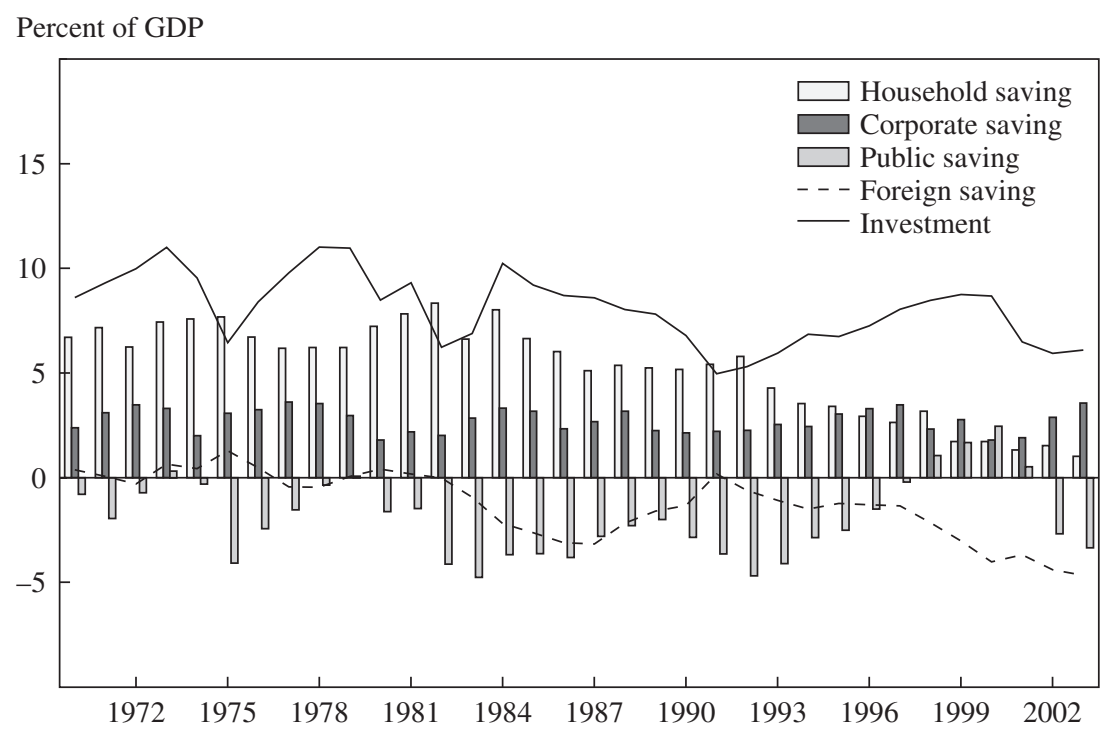

Source: Bureau of Economic Analysis, National Income and Product Accounts, International Investment Position. a. All series are on a net basis.

rice Obstfeld and Kenneth Rogoff, ${ }^{15}$ among others, have shown, if the U.S. deficit continues at its current level, in twenty-five years U.S. net international liabilities will exceed those recorded by any other country, as a percentage of GDP, in modern times.

During the last thirty years the only industrial countries to have had current account deficits in excess of 5 percent of GDP have been small ones: Australia, Austria, Denmark, Finland, Greece, Iceland, Ireland, Malta, New Zealand, Norway, and Portugal. What is even more striking is that very few countries, industrial or developing, have had large current account deficits that lasted for more than five years. Table 4 lists those countries that have had "persistently large" current account deficits at some time during the period 1970-2001. For purposes of this table, I define a country as having a "large deficit" if, in any year, its current

15. Obstfeld and Rogoff (2004). 
Table 3. Distribution of Current Account Deficits by World Region, 1970-2001

Percent of GDP

\begin{tabular}{lccccccc}
\hline Region & $\begin{array}{c}\text { No. of } \\
\text { countries }\end{array}$ & Mean & Median & $\begin{array}{c}\text { 1st } \\
\text { decile }\end{array}$ & $\begin{array}{c}\text { 1st } \\
\text { quartile }\end{array}$ & $\begin{array}{c}\text { 3rd } \\
\text { quartile }\end{array}$ & $\begin{array}{c}\text { 9th } \\
\text { decile }\end{array}$ \\
\hline 1970-2001 & & & & & & & \\
Industrial countries & 22 & 0.6 & 0.7 & -3.8 & -1.6 & 3.0 & 4.8 \\
$\begin{array}{l}\text { Latin America and } \\
\quad \text { Caribbean }\end{array}$ & 34 & 5.4 & 4.1 & -2.5 & 1.1 & 8.0 & 16.9 \\
Asia & 22 & 3.0 & 2.7 & -7.1 & -0.6 & 6.3 & 11.3 \\
Africa & 51 & 6.3 & 5.3 & -3.4 & 1.2 & 9.9 & 16.9 \\
Middle East & 12 & 0.0 & 1.4 & -18.8 & -5.0 & 6.4 & 13.6 \\
Eastern Europe & 25 & 3.9 & 3.0 & -2.4 & 0.3 & 6.1 & 10.7 \\
All countries & 169 & 3.9 & 3.3 & -5.0 & -0.1 & 7.1 & 13.1 \\
1984-2001 & & & & & & & \\
Industrial countries & 25 & 0.2 & 0.3 & -4.7 & -2.3 & 2.7 & 4.8 \\
Latin America and & 34 & 5.1 & 3.7 & -2.5 & 1.1 & 7.0 & 17.0 \\
$\quad$ Caribbean & & & & & & & \\
Asia & 22 & 2.2 & 2.4 & -8.0 & -1.3 & 5.9 & 10.2 \\
Africa & 51 & 5.9 & 4.6 & -3.5 & 0.9 & 9.1 & 16.2 \\
Middle East & 12 & 2.3 & 1.5 & -12.4 & -4.0 & 6.3 & 14.9 \\
Eastern Europe & 25 & 4.0 & 3.1 & -2.5 & 0.3 & 6.6 & 10.9 \\
All countries & 169 & 3.8 & 3.0 & -4.8 & -0.4 & 6.7 & 12.9 \\
\hline
\end{tabular}

Source: Author's calculations using data from World Bank, World Development Indicators.

account deficit exceeded its region's ninth decile. ${ }^{16} \mathrm{I}$ then define a "persistently large deficit" country as one that has at some time had a large deficit, as defined above, for at least five consecutive years. ${ }^{17}$ The resulting list in table 4 is extremely short, and none of the countries listed is large. This illustrates the fact that, historically, periods of large current account imbalances have tended to be short lived and have been followed by periods of current account adjustment.

Table 5 presents data on net international liabilities, as a percentage of GDP, for a group of industrial countries that have historically had a large negative NIIP position. ${ }^{18}$ The picture that emerges is different from that in

16. Notice that the thresholds for defining "large" deficits are year- and region-specific, with a different threshold for each region each year.

17. For an econometric analysis of the persistence of current account deficits see Edwards (2004). See also Taylor (2002).

18. Data for the United States are from the Bureau of Economic Analysis. For the other countries the data are from the Lane and Milesi-Ferretti data set up to 1997. I have updated them using national current account balance data. The updated figures should be interpreted with a grain of salt, because I have not corrected them for valuation effects. 
Table 4. Countries with Persistently Large Current Account Deficits by World Region, 1970-2001 ${ }^{\mathrm{a}}$

\begin{tabular}{lc}
\hline Region and country & Period \\
\hline Industrial countries & \\
Ireland & $1978-84$ \\
New Zealand & $1984-88$ \\
Latin America and Caribbean & $1979-85$ \\
Guyana & $1984-90,1992-2000$ \\
Nicaragua & $1982-89$ \\
Asia & \\
Bhutan & $1982-93$ \\
Africa & $1995-2000$ \\
Guinea-Bissau & \\
Lesotho & $1995-99$ \\
Eastern Europe & \\
Azerbaijan & \\
\hline $\begin{array}{l}\text { Source: World Bank, World Development Indicators, various years. } \\
\text { a. A persistently large deficit is defined as one that exceeded the ninth decile for the country's region for } \\
\text { at least five consecutive years. }\end{array}$
\end{tabular}

table 4: a number of industrial nations have had-and continue to havea significantly larger net international liabilities position relative to GDP than does the United States. This suggests that, at least in principle, the U.S. NIIP could continue to deteriorate for some time into the future. But, even if this should happen, at some point the process must come to an end, and the U.S. position as a percentage of GDP will have to stabilize. It makes a big difference, however, at what level it does stabilize. For example, if, in the steady state, foreigners are willing to hold at most the equivalent of 35 percent of U.S. GDP in the form of net U.S. assets, the United States could sustain a current account deficit of only 2.1 percent of U.S. GDP. ${ }^{19}$ If, on the other hand, foreigners' net demand for U.S. assets were to grow to 60 percent of GDP-which, as table 5 shows, is approximately the ratio of (net) foreign holdings of Australian assets to that country's GDP - the sustainable U.S. current account deficit would be 3.6 percent of GDP. And if foreigners are willing to hold (net) U.S. assets equivalent to 100 percent of U.S. GDP - the figure that Mussa considered implausible in the statement footnoted above-the sustainable U.S. current

19. This calculation assumes a 6 percent rate of growth of nominal GDP going forward. See below for an analytical discussion and the relevant equations. 
Table 5. Net Stock of Liabilities in Selected Industrial Countries, Selected Years Percent of GDP

\begin{tabular}{lccrrrr}
\hline Country & 1980 & 1985 & 1990 & 1995 & 2000 & 2003 \\
\hline Australia & n.a. & n.a. & 47.4 & 55.1 & 65.2 & 59.1 \\
Canada & 34.7 & 36.3 & 38.0 & 42.4 & 30.6 & 20.6 \\
Denmark & n.a. & n.a. & n.a. & 26.5 & 21.5 & 13.0 \\
Finland & 14.6 & 19.0 & 29.2 & 42.3 & 58.2 & 35.9 \\
Iceland & n.a. & n.a. & 48.2 & 49.8 & 55.5 & 66.0 \\
New Zealand & n.a. & n.a. & 88.7 & 76.6 & 120.8 & 131.0 \\
Sweden & n.a. & 20.9 & 26.6 & 41.9 & 36.7 & 26.5 \\
United States & -12.9 & -1.3 & 4.2 & 6.2 & 14.1 & 22.1 \\
\hline
\end{tabular}

Source: Bureau of Economic Analysis, U.S. International Transactions and International Investment Position, various years; Lane and Milesi-Ferretti (2001).

account deficit could be as large as 6 percent of GDP, or approximately its current level. ${ }^{20}$

Since there are no historical precedents for a large, advanced nation running persistently large current account deficits, it is extremely difficult to get a clear idea of how foreigners' demand for U.S. assets will behave in the future. Given this lack of historical precedent, a reasonable strategy is to model the RER dynamics to be expected if, as posited by Michael Dooley and his coauthors, ${ }^{21}$ among others, foreigners' demand for U.S. assets continued to increase. This is the approach followed in the next section.

\section{The Analytics of Current Account and Real Exchange Rate Adjustment}

The current account and the RER are endogenous variables jointly determined in a general equilibrium context. The key question is how these two variables will move in response to a given exogenous shock- $\mathrm{a}$ decline in capital inflows, say-if the other main variables, including economic growth and the rate of unemployment, do not deviate significantly from their long-term equilibrium paths. A number of authors have recently addressed this issue using a variety of simulation and econometric models.

20. Mussa (2004).

21. Dooley, Folkerts-Landau, and Garber (2004a). 
Most have asked what amount of RER adjustment would be "required" to achieve a certain current account balance. Among these, some have considered the case where the deficit is completely eliminated, ${ }^{22}$ whereas others have investigated the reduction of the deficit to a smaller but still positive level. Appendix table A-1, which summarizes a selection of these studies, shows that they have used different methodologies and reached different conclusions. ${ }^{23}$ All, however, find quite large required adjustments in the trade-weighted value of the dollar. ${ }^{24}$ The estimates from the studies summarized in table A-1 are much larger than those discussed in most investment bank newsletters and in the media. ${ }^{25}$

\section{A Portfolio Model of the Current Account and the Real Exchange Rate}

From an analytical perspective the process of current account adjustment may be broken down into two components: the dynamics of changes in net foreign assets, and the "transfer" associated with changes in a country's net foreign assets position. Changes in international investors' willingness to hold U.S. assets will affect total absorption of saving and relative prices, including the RER. An increase in foreigners' rate of accumulation of U.S. assets will allow the United States to increase its absorption, generating a real appreciation and a current account deficit. In a similar way, a reduction in the rate at which foreigners accumulate the country's assets-or, worse, a reduction in their holdings of domestic assets-will result in a slowdown or a drop in absorption and a decline in the relative price of nontradables, that is, a real depreciation. These changes in absorption and the concomitant adjustment in relative prices are reminiscent of discussions of the "transfer problem," which go back at least to the debates between John Maynard Keynes and Bertil Ohlin during the 1920s. In large countries such as the United States, however, the

22. For example, Obstfeld and Rogoff (2000, 2004); Blanchard, Giavazzi, and Sa (this volume).

23. See also the studies by Mann (2003, 2004), which extend her pioneering 1999 model.

24. See, for example, Blanchard, Giavazzi, and Sa (this volume).

25. Although many financial market practitioners do believe that the dollar will weaken, they tend to expect more moderate adjustments. See, for example, the forex publications of some major investment banks. 
story is more complex. First, as mentioned above, changes in relative prices have valuation effects on net foreign asset holdings, which will feed back into the dynamics of net foreign asset accumulation or decumulation. ${ }^{26}$ Second, in a large country, changes in aggregate expenditure are likely to affect the international terms of trade, and thus the general equilibrium outcome of the original shock.

THE BASIC MODEL. Consider the following barebones portfolio model of the current account. ${ }^{27}$ Equation 1, which is the basic equation for the external sector (expressed in domestic currency), states that the current account deficit (CAD) is equal to the trade deficit (TD) plus the income account (net income payments to the rest of the world, IA) plus net transfers to the rest of the world (NT):28

$$
\mathrm{CAD}_{t}=\mathrm{TD}_{t}+\mathrm{IA}_{t}+\mathrm{NT}_{t}
$$

The income account, in turn, is equal to

$$
\mathrm{IA}_{t}=i D_{t}^{f}-i^{*} F_{t}^{d},
$$

where $i$ is the interest rate paid on (gross) domestic assets in the hands of foreigners $D_{t}^{f}$, and $i^{*}$ is the interest rate on (gross) foreign assets held by domestic residents $F_{t}^{d}$. Since equation 1 is expressed in domestic currency,

$$
F_{t}^{d}=E_{t} F_{t}^{d^{*}}
$$

where $E$ is the nominal exchange rate, defined as units of domestic currency (in this case dollars) per unit of foreign currency, and $F_{t}^{d^{*}}$ denotes (gross) foreign assets held by domestic residents, expressed in foreign currency. Equation 1 can then be rewritten as

26. This effect has been emphasized by Lane and Milesi-Ferretti (2001, 2004a, 2004b), Tille (2003), and Gourinchas and Rey (2005), among others. For a discussion of valuation effects in the context of current account sustainability in emerging economies, see Edwards (2003).

27. To concentrate on the problem at hand and to keep the analysis tractable, I have made a number of simplifications; I have made no attempt to construct a full general equilibrium model. Recent papers that have constructed portfolio models of the current account include Blanchard, Giavazzi, and Sa (this volume), Edwards (1999, 2002), Gourinchas and Rey (2005), and Kraay and Ventura (2002).

28. I have defined current account balances such that a deficit is a positive number. In equation 1 , then, negative numbers refer to a surplus. 


$$
\mathrm{CAD}_{t}=\mathrm{TD}_{t}+i \delta_{t}+\left(i-i^{*}\right) F_{t}^{d}+\mathrm{NT}_{t},
$$

where $\delta$ is net domestic assets in the hands of foreigners, $\delta_{t}=D_{t}^{f}-F_{t}^{d}$. The terms $i \delta_{t}$ and $\left(i-i^{*}\right) F_{t}^{d}$ capture valuation effects on the current account, recently emphasized by a number of authors. ${ }^{29}$

Equation 2 is a portfolio balance equation that summarizes net international demand for the domestic country's assets $\delta_{t}$. Domestic and foreign assets are assumed to be imperfect substitutes. The variable $\alpha$ is the share of foreigners' wealth that they are willing to hold in the form of the domestic country's assets; $W$ is world wealth, and $W^{c}$ is the domestic country's wealth. The variable $\alpha_{j j}$ is the domestic country's asset allocation on its own assets, that is, the share of their wealth that domestic residents choose to hold in domestic assets. I assume that there is home bias in portfolio decisions; this is reflected in the fact that $\alpha$ and $\left(1-\alpha_{j j}\right)$ are below international market shares of domestic and foreign wealth. There is no need, however, to assume that foreign and domestic investors have the same degree of home bias. Hence the portfolio balance equation can be written as

$$
\delta_{t}=\alpha\left(W_{t}-W_{t}^{c}\right)-\left(1-\alpha_{j j}\right) W_{t}^{c} .
$$

An important question is how the asset allocation shares $\alpha$ and $\alpha_{j j}$ are determined. Under standard portfolio theory, $\alpha$ and $\alpha_{j j}$ will depend on expected real returns $\left(i, i^{*}\right)$, perceived risk $\left(\mu, \mu^{*}\right)$, and the degree of segmentation of international financial markets. Here, however, I make the simplifying assumption that $\alpha$ and $\alpha_{j j}$ are exogenously determined. This assumption allows me to focus on the effects of exogenous changes in portfolio allocations - that is, exogenous changes in $\alpha$ and $\alpha_{j j}$ - on net asset dynamics and the current account. More specifically, I consider the case where changes in $\alpha$ and $\alpha_{j j}$ reduce the initial extent of home bias. Later I discuss how the results are altered if some degree of substitutability between domestic and foreign assets is allowed.

World wealth in foreign currency $W^{*}$ and in domestic currency $W$ are related by $W_{t}^{*}=W_{t} / E_{t}$. Domestic and foreign interest rates are related by $i=i^{*}+\left(\mathrm{d} E^{e} / E\right)+\left(\mu-\mu^{*}\right)+k$, where $\left(\mathrm{d} E^{e} / E\right)$ is the expected rate of depreciation of the domestic currency, and $k$ is a term that captures the effect of capital controls; in a world of perfect capital mobility, $k=0$.

29. Including Lane and Milesi-Ferretti (2004a, 2004b) and Gourinchas and Rey (2005), among others. 
Note that in this model "investors" refers both to private and public investors, including foreign central banks. Indeed, as already pointed out, recent discussions have emphasized the key role played by foreign (and especially Asian) central banks in helping finance the U.S. current account deficit.

The counterpart of a current account deficit is the change in the country's (net) assets in the hands of foreigners:

$$
\mathrm{CAD}_{t}=\Delta \delta_{t}
$$

Equation 4 defines the trade deficit:

$$
\mathrm{TD}_{t}=\sum p_{i}^{m} m_{i}-\sum p_{i}^{x} x_{i},
$$

where $p_{i}^{m}$ and $p_{i}^{x}$ are prices of importables and exportables in domestic currency; $m_{i}$ is demand for importables, which is assumed to depend on the real exchange rate $e$, the international price of importable goods, the country's real income $y$, and other factors, including the degree of trade protection $v$. Demand for exports $x_{i}$, on the other hand, depends on the RER, the international price of exportables, rest-of-world real income $y^{*}$, and other factors $u$ :

$$
m_{i}=m_{i}(e, y, v) ; x_{i}=x_{i}\left(e, y^{*}, u\right) .
$$

Variables $m_{i}$ and $x_{i}$, in turn, may be interpreted as excess demand for importables and supply of exportables, respectively, in the domestic country. The basic version of the model assumes that the law of one price holds for both importables and exportables: $p_{i}^{m}=E p_{i}^{m *} ; p_{i}^{x}=E p_{i}^{x *}$. However, in the simulation exercises below, alternative assumptions can be made, including that exporters and importers price to market. Equation 6 is the equilibrium condition for the nontradable goods market in the domestic country, where $S_{t}^{N}$ is the supply of nontradables in period $t$, assumed to depend on the RER and other factors $z$, and $D_{t}^{N}$ is demand for nontradables:

$$
S_{t}^{N}\left(e_{t}, z_{t}\right)=D_{t}^{N}\left(e_{t}, y_{t}\right) .
$$

The domestic price level $P$ is assumed to be a geometric average of the nominal prices of tradable goods (importables and exportables) and nontradable goods: 


$$
P_{t}=\left(p_{t}^{m}\right)^{a}\left(p_{t}^{x}\right)^{b}\left(p_{t}^{N}\right)^{(1-a-b)} .
$$

Equation 7 defines the real exchange rate:

$$
e_{t}=P_{t} / E_{t} P_{t}^{*},
$$

where $P_{t}^{*}$ is the foreign price level. As before, an increase in $e$ represents a real appreciation.

The interpretation of this model is simple. The domestic country can run a current account deficit only to the extent that foreign investors are willing to increase their net holdings of domestic assets - that is, to the extent that $\Delta \delta_{t}>0$. Once $\Delta \delta_{t}$ is known, and for given values of other key variables, it is possible to derive the real exchange rate $e$ consistent with the prevailing current account deficit or surplus. A particularly interesting exercise, given the current U.S. situation, is to analyze how exogenous changes in portfolio preferences-that is, changes in $\alpha, \alpha_{j j}$, or both-will affect the current account and the RER.

Closing the model would require specifying a number of market clearing conditions, including the saving and investment equations for the world economy; and the world market clearing conditions for each importable and exportable good. These equilibrium conditions determine endogenously both interest rates and all relevant tradable goods prices. Doing this, however, would make the model significantly more complex than is required for dealing with the problem at hand. For this reason I work with a partial equilibrium version of the model, under alternative assumptions regarding these variables' behavior. ${ }^{30}$

It is important to emphasize that current account adjustment not only implies changes in the RER, but also requires changes in saving and investment in the domestic country (here the United States) and the rest of the world. From a policy perspective the adjustment in domestic saving would be greatly facilitated by an increase in public sector saving.

PORTFOLIO EQUILIBRIUM, DYNAMICS, AND CURRENT ACCOUNT SUSTAINABILITY. External sustainability requires that a country's net external liabilities stabilize at a level compatible with foreigners' net demand for these claims, as specified by equation 2 . On the assumption that the domestic country's wealth is a multiple $\lambda$ of its (potential or full-

30. Most recent models on global imbalances and the U.S. current account have used a partial equilibrium framework in the simulation phase. 
employment) GDP, and that its wealth is a fraction $\beta$ of world wealth $W$, it is possible to rewrite (international) net demand for the country's assets as $\delta=\left[\alpha \theta-\left(1-\alpha_{j j}\right)\right] \lambda Y$, where $Y$ is potential GDP, and $\theta=(1-\beta) / \beta=$ $E W^{f *} / W^{c}$, where $W^{f *}$ is rest-of-world wealth expressed in foreign currency.

Denoting $\gamma^{*}=\left[\alpha \theta-\left(1-\alpha_{j j}\right)\right] \lambda$, then $\delta=\gamma^{*} Y$. This means that in long-run equilibrium net international demand for the domestic country's assets can be expressed as a proportion $\gamma^{*}$ of its potential or sustainable GDP. The determinants of this factor of proportionality $\gamma^{*}$ depend on relative returns and the perceived risk of the domestic country and of the rest of the world, as well as on the degree of integration of international financial markets.

If $g$ is the country's sustainable rate of growth and $\pi$ the country's long-term rate of inflation, the "sustainable" ratio of the current account deficit to GDP is given by

$$
\mathrm{CAD} / Y=(g+\pi)\left[\alpha \theta-\left(1-\alpha_{j j}\right)\right] \lambda=\gamma^{*}(g+\pi) .
$$

Notice that, if $\left[\alpha \theta-\left(1-\alpha_{j j}\right)\right]<0$, domestic residents' demand for foreign assets exceeds foreigners' demand for domestic country assets. Under these circumstances the country will have to run a current account surplus in order to maintain a stable net external assets-to-GDP ratio. Most studies of the sustainability of the U.S. current account have used equations of this type. Mussa, ${ }^{31}$ for example, argues that in long-term equilibrium $\gamma^{*}$ is likely to be around $0.50 .{ }^{32}$ In long-run equilibrium the sustainable trade balance will be given by $\mathrm{TD} / Y=(g-r) \gamma^{*}$, where $r$ is the real interest rate.

In this model, as in earlier models developed by myself and by Aart Kraay and Jaume Ventura, ${ }^{33}$ additional saving will be allocated in a way that maintains domestic and foreign assets in the same proportion as in the original portfolio. Kraay and Ventura have shown that models that combine this assumption with the assumption of transactions costs in investment go a long way toward explaining international current account behavior in a large number of countries.

If the degree of perceived riskiness of the domestic country (exogenously) declines, $\alpha$, and thus $\gamma^{*}$, will increase. As a result, the sustainable

31. Mussa (2004).

32. See also Edwards (1995), Ades and Kaune (1997), and O'Neill and Hatzius (2004) for current account sustainability analyses of this type.

33. Edwards (1999); Kraay and Ventura (2002). 
current account balance will deteriorate (see equation 9). Equally important, changes in portfolio allocation, generated by changes in $\alpha$ or $\alpha_{j j}$, will generate a dynamic adjustment process, during which the current account will differ from its long-run sustainable level. This transitional dynamic can be incorporated into the model through the following equation:

$$
(\mathrm{CAD} / Y)_{t}=(g+\pi) \gamma_{t}^{*}+\psi\left(\gamma_{t}^{*}-\gamma_{t-1}\right)-\kappa\left[(\mathrm{CAD} / Y)_{t-1}-(g+\pi) \gamma_{t}^{*}\right]
$$

According to equation 9, short-term deviations of the current account from its long-run level can result from two forces. The first is a traditional stock adjustment term $\left(\gamma_{t}^{*}-\gamma_{t-1}\right)$ that captures deviations between the demanded and the actual stock of the country's assets in the hands of foreign investors. The coefficient $\psi$ is the speed of adjustment, which will depend on a number of factors, including the degree of capital mobility in the country in question. The second force affecting this dynamic process, captured by $-\kappa\left[(\mathrm{CAD} / Y)_{t-1}-(g+\pi) \gamma_{t}^{*}\right]$ in equation 9 , is a self-correcting term, included to ensure that some form of consumption smoothing is present. The importance of this self-correcting term will depend on the value of $\kappa .^{34}$

Whether the dynamic representation in equation 9 is appropriate is, in the final analysis, an empirical matter. As I show below, under certain parameterizations this model does a very good job at tracking the behavior of the U.S. current account during the last few years. The dynamic behavior for the net stock of the domestic country's assets in the hands of foreigners, as a percentage of GDP, will be given by $\gamma_{t}=\left[\gamma_{t-1}+\right.$ $\left.(\mathrm{CAD} / Y)_{t-1}\right](1+g+\pi)^{-1}$.

Consider the case where for some exogenous reason the home bias in the rest of the world is reduced-that is, $\alpha$ in equation 2 increases. This will result in an increase in the sustainable current account deficit (equation 8). It will also unleash a dynamic adjustment process, captured by equation 9. During this transitional period the current account deficit will exceed its new long-run (higher) sustainable equilibrium; that is, the current account deficit will overshoot its new sustainable level. During the transition the trade account will move according to the following equation: $\Delta(\mathrm{TD} / Y)_{t}=\Delta(\mathrm{CAD} / Y)_{t}-\Delta\left(i \gamma_{t}^{*}\right)-\Delta\left[\left(i-i^{*}\right)\left(F^{d} / Y\right)\right]_{t}-\Delta(\mathrm{NT} / Y)_{t}$. From

34. If $\psi=\kappa=0$, the current account will jump from one sustainable level to the next. There are many reasons to assume that both $\psi$ and $\kappa$ are different from zero, including the existence of adjustment costs in consumption. 
equations 4 through 6 , and after making some assumptions regarding the behavior of other key variables, such as the international terms of trade and interest rates, the following equation for the current account may be derived (to simplify the notation, the $m_{i}$ and $x_{i}$ have been aggregated into broad import and export categories):

$$
\begin{aligned}
& \Delta(\mathrm{CAD} / Y)_{t}-\Delta\left(i \gamma_{t}^{*}\right)+\Delta\left[\left(i-i^{*}\right)\left(F^{d} / Y\right)_{t}\right]+\Delta(N T / Y)_{t} \\
& +\left[\sigma_{x}\left(1+\varepsilon_{e}\right)-\sigma_{m}\left(1+\eta_{e}\right)\right] \hat{e}+\left(\sigma_{m}-\sigma_{x}\right)\left(\pi-\pi^{*}\right)+\sigma_{m} \eta_{y} g \\
& -\sigma_{m} \varepsilon_{y *} g^{*}+\sigma_{m} \hat{p}_{m}^{*}-\sigma_{x} \hat{p}_{x}^{*}-\left(\sigma_{m}-\sigma_{x}\right)(g+\pi),
\end{aligned}
$$

where $\sigma_{m}$ and $\sigma_{x}$ are ratios of imports and exports to GDP; $\eta_{e}<0$ and $\varepsilon_{e}>$ 0 are the price elasticities of imports and exports, respectively; $\eta_{y}$ and $\varepsilon_{y}^{*}$ are the elasticities of imports and exports with respect to domestic and foreign income, respectively; $g$ and $g^{*}$ represent rates of real GDP growth at home and in the rest of the world, respectively; $\pi$ and $\pi^{*}$ are domestic and world inflation, respectively; $\hat{p}_{m}^{*}$ and $\hat{p}_{x}^{*}$ are the rates of change in international prices of imports and exports, respectively; and $\hat{e}$ is the rate of change of the real exchange rate. From this equation it follows that, in order for a real depreciation to improve the trade balance (and, other things equal, the current account $)$, it is required that $\left[\sigma_{x}\left(1+\varepsilon_{e}\right)-\right.$ $\left.\sigma_{m}\left(1+\eta_{e}\right)\right]>0 .{ }^{35}$

Although equation 10 is not a reduced-form equation, it is useful for undertaking a number of simulation exercises. ${ }^{36}$ For example, with equations 2, 3, 9, and 10, and under assumed values for growth, inflation, and interest rates and changes in the international terms of trade, it is possible to analyze how changes in portfolio preferences will affect the trajectories of the current account and the RER.

\section{Simulation Results}

The barebones model developed above may be used to compute the current account and RER adjustments consistent with shifts in portfolio

35. Under balanced initial trade, this expression becomes the traditional MarshallLerner condition.

36. In equation $10 \mathrm{I}$ have assumed that $\mathrm{d} i=\mathrm{d} i^{*}=0$. Since $\alpha$ and $\alpha_{j j}$ are exogenous, this assumption does not affect the behavior of the RER. Later in the paper I discuss the way in which changes in interest rates and other variables such as the international terms of trade affect the results. 
preferences by foreign and domestic investors, including a reduction in the home bias in portfolio investment decisions. ${ }^{37} \mathrm{~A}$ first step in this analysis is to calibrate the model. Table A-2 in the appendix presents the parameter values used in the base-case simulation; most of these values are taken from existing studies of the U.S. and world economies. I have selected the values of $\psi$ and $\kappa$ that best track the actual dynamics of the U.S. current account between 1996 and 2004; the best results are obtained for $\psi=0.30$ and $\kappa=0.20$. I also assume that foreigners' demand $\alpha$ for U.S. assets increased gradually from 0.205 to 0.300 between 1996 and 2004 (see the values for $\alpha_{\text {Historical }}$, and $\alpha_{\text {Initial }}$ in table A-2). As may be seen from the top left and bottom right panels of figure 5, for these parameter values the model tracks actual current account and RER behavior for 1996-2004 quite closely. ${ }^{38}$

One limitation of this type of simulation exercise is that it is difficult to forecast how foreign investors' net demand for U.S. assets will behave in the future. It is precisely for this reason that a number of authors have avoided the issue and have instead computed the RER adjustment "required" to eliminate the current account deficit completely. ${ }^{39}$ Here I take a different approach: instead of assuming that the current account deficit has to be reduced to zero or some other arbitrary number, I analyze the dynamic of the current account under alternative assumptions regarding foreigners' net demand for U.S. assets. I am particularly interested in understanding what is likely to happen under an optimistic scenario where foreigners' demand for U.S. assets continues to grow. What makes this approach particularly interesting is the finding that, even under such a scenario, it is highly likely that, in the not-too-distant future, the U.S. current account will undergo a significant reversal.

As table A-2 shows, in these simulation exercises I assume a gradual portfolio adjustment over the next five years. I assume that $\alpha$ increases from its current value of 0.30 to 0.40 by 2010 and that $\alpha_{j j}$ falls from 0.73

37. In fact, there are indications that the process of international capital market integration will continue in the future, as some of the largest emerging economies, including China, are increasingly allowing their nationals to invest abroad. See, for example, "China to Seek Full Currency Conversion," Financial Times, February 28, 2005, p. 6.

38. To obtain the best possible historical fit for the model, I incorporated into the historical simulation changes in the terms of trade that track what was observed in 1996-2004.

39. Obstfeld and Rogoff (2000, 2004). For similar approaches see Mussa (2004) and Blanchard, Giavazzi, and Sa (this volume). 

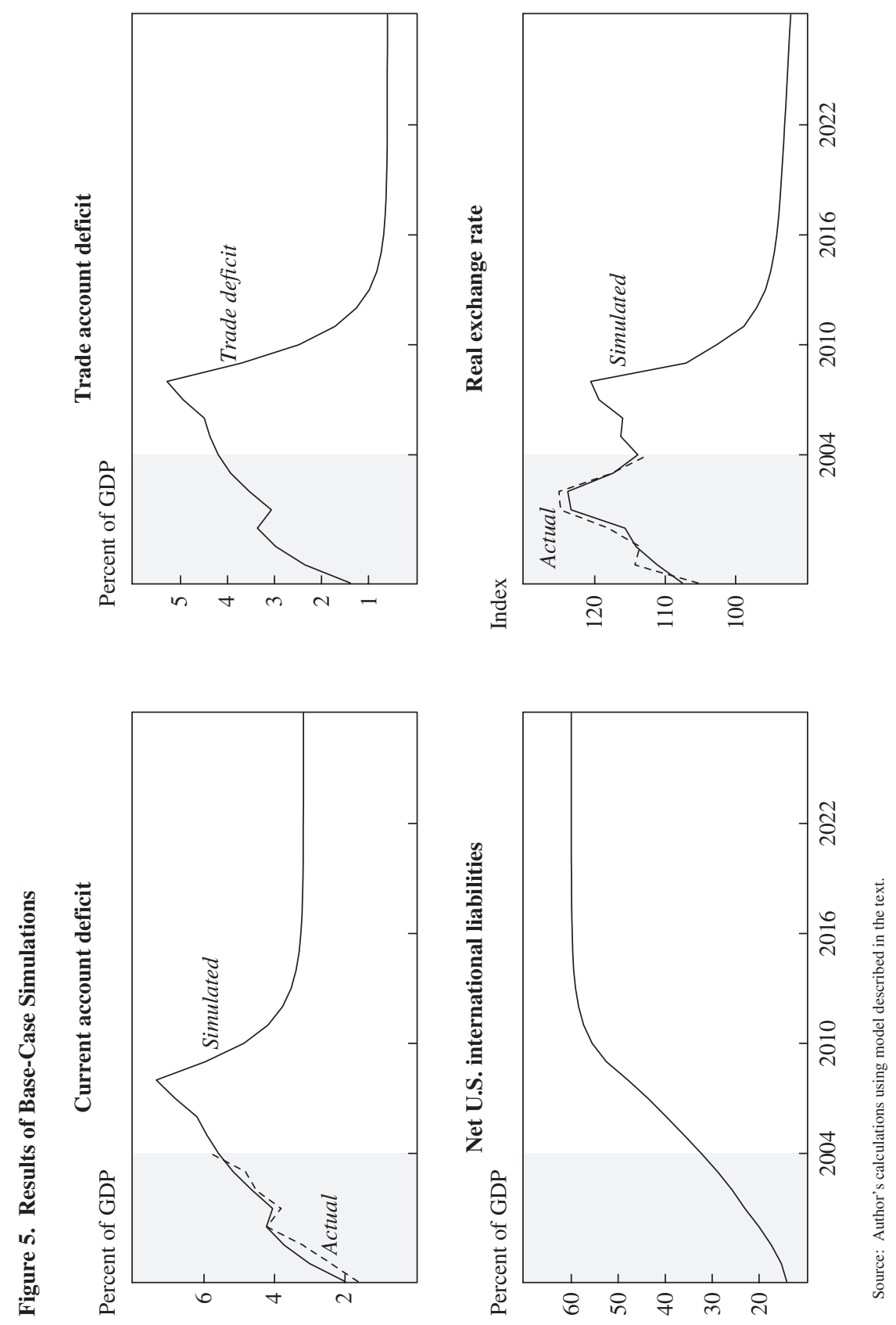
to 0.71 during the same period. This adjustment implies a reduction in home bias both in the rest of the world and in the United States. In the base-case scenario the assumed portfolio adjustment is equivalent to foreigners doubling their net demand for U.S. assets to an amount equal to 60 percent of U.S. GDP. This is a very large number. Indeed, it implies that, under the assumptions that $g=0.03$ and $\pi=0.023$, during the five years from 2005 to 2010 the U.S. NIIP will deteriorate by a further $\$ 5.7$ trillion.

Before proceeding, the following assumptions made in the base-case scenario deserve some comment (see table A-2 for details). First, I assume that the United States and the rest of the world grow at the same rate $\left(g=g^{*}\right)$. This is consistent with the idea that, while the United States will grow faster than Europe and Japan, the rest of the world-including China and India-will continue to grow very rapidly. In a number of alternative simulations I consider different values for growth. A second assumption concerns the values of the key elasticities, which have been taken from existing studies on the U.S. and global economies. ${ }^{40}$ Two important characteristics of these elasticities are that the income elasticity for U.S. imports exceeds that for imports by the rest of the world (the socalled Houthakker-Magee phenomenon), and that the RER elasticity of U.S. imports exceeds (in absolute terms) that of U.S. exports. Finally, in the base-case scenario I assume that the adjustment has no effect on the international terms of trade $\left(\hat{p}_{m}^{*}=\hat{p}_{x}^{*}=0\right)$; in alternative simulations I consider the case where the terms of trade change.

BASE-CASE SIMULATIONS. Figure 5 presents the results of this basecase exercise. In these simulations, 2005 should be interpreted as the "initial" period; the previous eight years (the shaded area) represent recent history. The figure presents simulation results for the current account, the trade account, net U.S. assets held by foreigners, and the trade-weighted RER index (and, for the eight historical years, the actual RER index). The most salient features of the base-case simulation are the following:

-Under the deliberately optimistic assumption of a significant increase in foreign net demand for U.S. assets, the current account deficit continues to increase until it peaks at 7.3 percent of U.S. GDP. From that point onward the deficit declines toward its new steady state of 3.2 percent of GDP.

40. See Hooper, Johnson, and Marquez (2000). 
-Once the current account deficit reaches its peak, the reversal is quite sharp. In the base-case scenario, during the first three years of adjustment the deficit is reduced by 3.1 percent of GDP. The reversal of the trade deficit is even sharper. The reason is that, with a larger net U.S. debtor position, net payments (interest and dividends) to foreign investors increase significantly relative to GDP.

-As the bottom right panel shows, once the process of current account reversal begins, the trade-weighted RER index falls rapidly: during the first three years of adjustment, the accumulated real depreciation is 13.3 percent. By the time the new, sustainable current account deficit is reached, the accumulated depreciation amounts to 22.5 percent. This result is roughly in line with other studies (table A-1). In alternative simulations in which the valuation effect of dollar depreciation on the U.S. net foreign asset position is ignored, the resulting real depreciation is larger: for example, in the first three years of adjustment the accumulated depreciation is 16.8 percent.

- This simulation also indicates that the new steady state is associated with a sharp depreciation: the RER falls to 19.1 percent below its initial (2005) level.

Alternative assumptions regarding growth, inflation, interest rates, the terms of trade, elasticities, and other key parameters will, of course, affect the results. Except when the changes in the assumptions are extreme, however, the main qualitative result holds: even under very optimistic assumptions regarding foreigners' net demand for U.S. assets, the current account deficit is likely to go through a large reversal in the not-too-distant future.

ALTERNATIVE PORTFOLIO CHOICES. An important question is how sensitive these results are to portfolio choices. To explore this issue, I report in figure 6 results from a second simulation exercise, which assumes that, after increasing their net holdings of U.S. assets to 60 percent of U.S. GDP by 2010, foreign investors make a new portfolio adjustment and gradually reduce their desired holdings of U.S. assets to 50 percent of U.S. GDP. (The bottom left panel of the figure depicts the trajectory of net foreign holdings of U.S. assets in this simulation.) As the figure shows, in this case the current account reversal is significantly more abrupt, as is the depreciation in terms of the trade-weighted RER index. In the first three years of the adjustment, the current account deficit declines by 5.3 percent of GDP, and the accumulated depreciation 

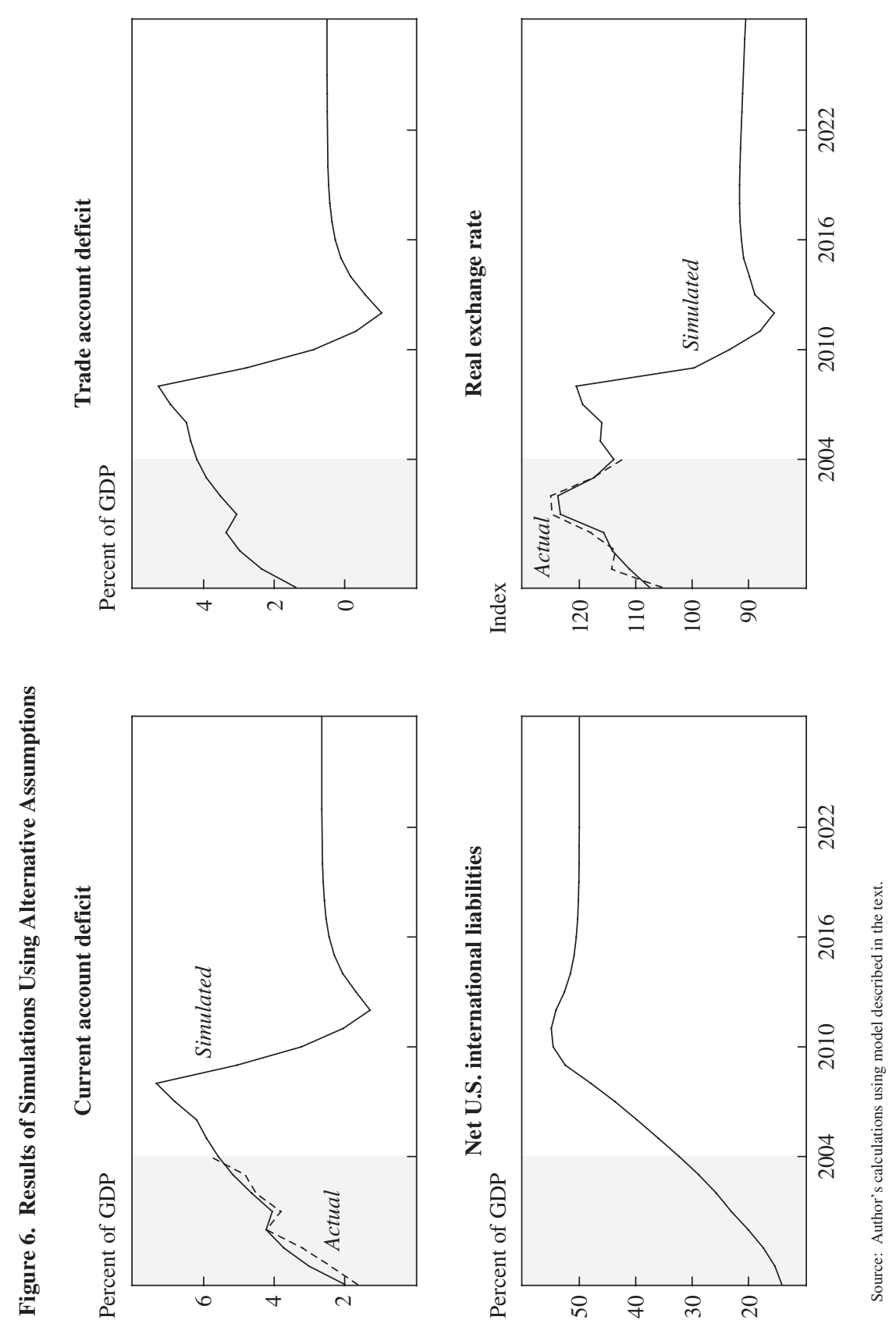
is 23.7 percent. Moreover, as the top right panel of the figure shows, by the third year of the adjustment (2011 in the simulation), the trade deficit has turned into a surplus. It is important to keep in mind that this simulation still assumes that the long-run net demand by foreigners for U.S. assets is still significantly higher-20 percent of GDP higher, to be precise-than today. Because of space considerations, I have not presented the results of more pessimistic scenarios in which foreigners reduce their net demand for U.S. assets below the current level. Suffice it to say that in those scenarios the current account reversal is even more pronounced, as is the concomitant real depreciation.

DOES ADJUSTMENT NEED TO BE ABRUPT? The results presented in figures 5 and 6 , and in particular the abrupt current account reversal that takes place after the deficit peak is reached, depend on the assumptions made about parameters $\psi$ and $\kappa$; different values of these parameters would result in different dynamics. For instance, if in the future the dynamic of the adjustment process changes, such that $\psi$ declines while $\kappa$ increases, this would result in a more gradual convergence of the current account deficit to its new, sustainable level. To take a concrete example, values of $\psi=0.20$ and $\kappa=0.35$ would result in an accumulated compression of the current account of 1.9 percent of GDP during the first four years of the adjustment process. This is a significantly less drastic adjustment than the 6 percent of GDP obtained in figure 6 , and it shows that an abrupt collapse in the deficit is not unavoidable. Furthermore, in this simulation the current account deficit would peak at 6.2 percent of GDP (results not shown) rather than at 7.3 percent as in figure 6.

The process of net accumulation of U.S. assets by foreigners may also differ from what I have assumed in both simulations. For instance, if they slow their accumulation of U.S. assets, or if they stretch the process over a longer period, the eventual adjustment would be less abrupt than is depicted in figures 5 and 6 . The real depreciation of the trade-weighted dollar might also be less pronounced. This would be the case, for example, if U.S. saving were to increase in the next few years, moving closer to its historical average. In that case expenditure reduction would play a more significant role in the adjustment, and expenditure switching (through dollar depreciation) would be less important.

The simulations discussed above assumed an exogenously given rate of growth of GDP. This, of course, need not be the case in reality. It is likely, in fact, that current account reversals of the type and magnitude 
suggested by the simulation results will have an effect on real economic activity ${ }^{41}$ In the next section I use a new, comparative cross-country data set to investigate the real consequences of current account reversals in the world economy since 1971. This comparative analysis will help give some idea of the possible effects of a U.S. current account reversal like that in the simulations in figures 5 and 6.

\section{How Costly Are Current Account Reversals? An International Comparative Analysis}

The main message of the simulation exercises just presented is that, even under optimistic scenarios where foreigners' demand for U.S. assets increases significantly, the U.S. current account experiences a significant reversal in the not-too-distant future. But what will be the nature of the adjustment process? I address this issue here by analyzing the international experience with current account reversals in the period 1971-2001. Although the U.S. case is unique, both because of the size of its economy and because the dollar is the world's main vehicle currency, an analysis of the international experience will shed some light on the likely nature of the adjustment. A particularly important question is whether this adjustment will entail real costs in the form of slower (or negative) growth and higher unemployment. Previous studies have generated conflicting results: after analyzing the evidence from a large number of countries, Gian Maria Milesi-Ferretti and Assaf Razin conclude that major current account reversals have not been costly: "reversals," they claim, "are not systematically associated with a growth slowdown. ${ }^{42}$ Jeffrey Frankel and Eduardo Cavallo, on the other hand, conclude that sudden stops of capital inflows (a phenomenon closely related to reversals) have resulted in growth slowdowns. ${ }^{43}$

41. See the pioneering study on current account reversals by Milesi-Ferretti and Razin (2000). See also Edwards (2004).

42. Milesi-Ferretti and Razin (2000, p. 303).

43. Frankel and Cavallo (2004). 
In what follows I analyze several aspects of current account reversals, including ${ }^{44}$

- their incidence

- the relationship between reversals and sudden stops of capital inflows

- the relationship between reversals and depreciation

- the factors determining the probability of a country experiencing a reversal, and

- the costs, in terms of slower growth, of reversals.

In analyzing these issues I rely on two complementary statistical approaches: First, I use nonparametric tests to analyze the incidence and main characteristics of current account reversals. Second, I use panel regression-based analyses to estimate the probability of a country experiencing a reversal, and the cost of such a reversal in terms of a short-term decline in output growth. Although the data set covers all regions of the world, in an effort to shed light on the U.S. case, I emphasize the experience of large countries. ${ }^{45}$

\section{Current Account Reversals during 1971-2001:}

The International Evidence

I use two definitions of current account reversals: I define a type I reversal as a reduction in the current account deficit of at least 6 percent of GDP within a three-year period, and a type II reversal as a reduction in the current account deficit of at least 4 percent of GDP in one year. (In both cases the reversal is recorded as occurring in the year when the episode ends. For example, if a country's current account deficit declined by 7 percent of GDP between 1980 and 1982, the episode is recorded as having taken place in 1982. Also, for an episode to count as a current

44. In Edwards (2004) I used a smaller data set to investigate reversals in emerging economies. In that paper, however, I did not consider the experience of large or industrial countries with reversals. I also used a very simple framework for analyzing growth. In contrast, in this section I use a two-step dynamic of growth approach.

45. Croke, Kamin, and Leduc (2005) recently analyzed the nature of current account adjustments in industrial economies. Their analysis differs from mine in several respects. First, they concentrate on milder current account adjustments; second, their sample includes only industrial countries; and, third, they are interested in analyzing whether there is likely to be a "disorderly" adjustment, defined as a situation of financial disruption. 
account deficit reversal, the initial balance has to be indeed a deficit. ${ }^{46}$ ) Thus, in a type I reversal, the magnitude of the adjustment is more pronounced than in a type II reversal but is distributed over a longer period. ${ }^{47}$

Table 6 presents data on the incidence of both types of reversal for the complete sample of countries as well as for each of the six groups of countries considered in the previous section. For the overall sample the incidence of type I reversals is 9.2 percent, and that of a type II reversal is 11.8 percent. The incidence of reversals among the industrial countries is much smaller, however, at 2.7 percent and 2.0 percent, respectively. Indeed, the Pearson $\chi^{2}$ and $\mathrm{F}$ tests reported in table 6 indicate that the hypothesis of equal incidence of reversals across regions is rejected strongly.

The industrial countries that experienced type I current account reversals during the period are Finland (in 1978 and 1994), Greece (1988), Ireland (1984), New Zealand (1977-78 and 1988-89), Norway (1979-80, 1989, and 2000), and Portugal (1979 and 1984-85). Those that experienced type II reversals are Austria (1982), Canada (1982), Greece (1986), Iceland (1983 and 1986), Ireland (1975), Italy (1975), Malta (1997), New Zealand (1978), Norway (1989), and Portugal (1982-83 and 1985). With the exception of Italy and Canada, all of these countries are economically very small, underlining the point that there are no historical precedents of large countries undergoing profound current account adjustments. As pointed out above, this implies that the results reported here on current account reversals should be interpreted with a grain of salt and should not be mechanically extended to the case of the United States.

The analysis presented above distinguished countries by their stage of development and world region. An alternative way of dividing the sample, and one that is particularly relevant for deriving lessons for the United States, is by economic size. I define "large" countries as those whose GDP placed them in the top 25 percent of the sample distribution in 1995 (by this criterion there are forty-one "large" countries in the sample). For the period 1971-2001 the incidence of type I reversals

46. These definitions differ somewhat from those used in other studies, including Freund (2000), Milesi-Ferretti and Razin (2000), Edwards (2002), and Guidotti, Villar, and Sturzenegger (2003).

47. Notice that it is possible for a country to have experienced both a type I and a type II reversal during the same historical episode. 
Table 6. Incidence of Current Account Reversals by World Region, 1970-2001 Percent $^{\mathrm{a}}$

\begin{tabular}{|c|c|c|c|c|}
\hline \multirow[b]{2}{*}{ Region or country group } & \multicolumn{2}{|c|}{ Type I reversal } & \multicolumn{2}{|c|}{ Type II reversal } \\
\hline & No reversal & $\overline{R e v e r s a l}$ & No reversal & Reversal \\
\hline Industrial countries & 97.3 & 2.7 & 98.0 & 2.0 \\
\hline Latin America and Caribbean & 92.0 & 8.0 & 87.7 & 12.3 \\
\hline Asia & 88.3 & 11.7 & 87.7 & 12.3 \\
\hline Africa & 88.3 & 11.7 & 83.4 & 16.6 \\
\hline Middle East & 86.6 & 13.4 & 85.0 & 15.0 \\
\hline Eastern Europe & 90.7 & 9.3 & 88.9 & 11.1 \\
\hline All countries & 90.8 & 9.2 & 88.2 & 11.8 \\
\hline \multicolumn{5}{|l|}{ Summary statistics } \\
\hline Uncorrected Pearson $\chi^{2}$ (5) & \multicolumn{2}{|c|}{37.31} & \multicolumn{2}{|c|}{67.42} \\
\hline Design-based $F$ test $(5,12,500)$ & \multicolumn{2}{|c|}{7.46} & \multicolumn{2}{|c|}{13.08} \\
\hline P-value & \multicolumn{2}{|c|}{0.00} & \multicolumn{2}{|c|}{0.00} \\
\hline
\end{tabular}

Source: Author's calculations using data from World Bank, World Development Indicators, various years.

a. Number of reversal episodes divided by the product of all countries in the group and all years, times 100 .

among large countries is 5.3 percent, and that of type II reversals is 6.8 percent.

\section{Current Account Reversals and Sudden Stops of Capital Inflows}

In the last few years a number of authors have analyzed episodes of sudden stops of capital inflows into a country ${ }^{48}$ From an analytical perspective, sudden stops and current account reversals should be closely related phenomena, but there is no reason for them always to occur together. Indeed, because of changes in international reserves, it is perfectly possible for a country to suffer a sudden stop without simultaneously experiencing a current account reversal. However, in countries with floating exchange rates, changes in international reserves tend to be relatively small, and, at least in principle, the relationship between sudden stops and reversals should be stronger.

To investigate formally the relationship between these two phenomena, I define a "sudden stop" episode as an abrupt and major reduction in capital inflows to a country that until that time had been receiving large volumes of foreign capital. Specifically, I impose the following criteria: capital inflows into the country in question during the two years preceding

48. See Calvo, Izquierdo, and Mejia (2004); Edwards (2004). 
the episode must have been larger (relative to GDP) than those of three quarters of the countries in its region; and net capital inflows must have declined by at least 5 percent of GDP in the year of the episode itself. ${ }^{49}$

Table 7 presents summary statistics, for three country samples, on the coincidence of sudden stops and current account deficit reversals (under both definitions of the latter). The first sample consists of large countries, defined, as stated above, as those whose GDP is in the top quartile of the sample distribution; the second consists of industrial countries only; and the third is the complete sample. The bottom panel of the table shows, in the first column, that 21.1 percent of all countries experiencing a sudden stop also faced a type I current account reversal, and 15.0 percent of those with type I reversals also experienced (in the same year) a sudden stop. The bottom panel also shows, in the second column, that 51 percent of all countries subjected to a sudden stop faced a type II current account reversal, and that 26.7 percent of those experiencing a type II reversal also suffered (in the same year) a sudden stop. The $\chi^{2}$ tests indicate that in both cases the hypothesis of independence between reversals and sudden stops is rejected. The data for the industrial countries show that the joint incidence of type I reversals and sudden stops is rather low for this group. In fact, according to the $\chi^{2}$ test, the null hypothesis of independence between the two phenomena cannot be rejected. The relationship between sudden stops and type II reversals, however, is somewhat stronger than for type I reversals among this group: the hypothesis of independence is rejected $\left(\chi^{2}=23.6 ; p=0.00\right)$. The results for large countries are similar to those for industrial countries.

An analysis of the lead-lag structure of reversals and sudden stops suggest that sudden stops tend to occur either before or at the same time (during the same year) as current account reversals. Indeed, a series of nonparametric $\chi^{2}$ tests rejects the hypothesis that current account reversals precede sudden stops (results not shown).

\section{Current Account Reversals and the Exchange Rate}

An important policy question - and one that is particularly relevant for the current policy debate in the United States-is whether current account

49. To check the robustness of the results, I also used two alternative definitions of sudden stops, which considered a reduction in inflows of 3 and 7 percent of GDP in one year. Detailed results using these definitions are not reported here. 
Table 7. Conditional Incidence of Current Account Reversals and Sudden Stops of Capital Inflows, 1970-2001

Percent

\begin{tabular}{lcc}
\hline Country sample and event & Type II reversal \\
\hline Large countries & Type I reversal & \\
Reversal $\mid$ Sudden stop & & \\
Sudden stop |Reversal & 9.3 & 25.5 \\
$\quad \chi^{2}(1)$ & 7.0 & 15.6 \\
$\quad$ P-value & 1.3 & 27.5 \\
Industrial countries & 0.26 & 0.00 \\
Reversal $\mid$ Sudden stop & & \\
Sudden stop|Reversal & 5.0 & 18.2 \\
$\quad \chi^{2}(1)$ & 7.1 & 28.6 \\
P-value & 0.4 & 23.6 \\
All countries & 0.51 & 0.00 \\
Reversal|Sudden stop & & \\
Sudden stop |Reversal & 21.1 & 51.0 \\
$\quad \chi^{2}(1)$ & 15.0 & 26.7 \\
P-value & 26.6 & 262.5 \\
\hline
\end{tabular}

Source: Author's calculations from data in World Bank, World Development Indicators, various years.

a. $x \mid y$ denotes the probability of $x$ occurring given the occurrence of $y$ in the same year.

reversals have historically been associated with unusually large depreciations. The starting point for my analysis of this issue is the construction of an index of "external pressures" along the lines suggested by Barry Eichengreen and others: ${ }^{.0}$

$$
I_{t}=\Delta E / E-\left(\sigma_{E} / \sigma_{R}\right)(\Delta R / R),
$$

where $\Delta E / E$ is the rate of change of the nominal exchange rate, $\Delta R / R$ is the rate of change of international reserves, and $\sigma_{E}$ and $\sigma_{R}$ are the standard deviations of changes in the RER and in international reserves, respectively. Traditional analyses define a crisis to have occurred when $I_{t}$ exceeds the mean of the index plus $k$ standard deviations. My crisis indicator $C_{t}$ thus takes a value of 1 (crisis) or zero (no crisis) according to the following rule: ${ }^{51}$

50. Eichengreen, Rose, and Wyplosz (1996).

51. The pioneering work here is that by Eichengreen, Rose, and Wyplosz (1996), who suggested that the index (equation 11) also include changes in domestic interest rates. The original index, however, has limited use in broad comparative analyses, because most emerging and transition economies do not have long time series on interest rates. For this reason, most empirical analyses are based on a restricted version of the index such as equation 11 . 


$$
C_{t}=\left\{\begin{array}{l}
1, \text { if } I_{t} \geq \text { mean }\left(I_{t}\right)+k \sigma_{1} \\
0, \text { otherwise. }
\end{array}\right.
$$

Using equation 12, I define two currency crisis indicators: The first (crisis type A) uses the traditional crisis index and assigns $C_{t}$ a value of 1 when $k \geq 3$. The second (crisis type B) looks to the nominal exchange rate to determine the value of $C_{t}$. In this case $I_{t}=\Delta E / E$, and $C_{t}=1$ if $I_{t} \geq \operatorname{mean}\left(I_{t}\right)$ $+k \sigma_{E}$ and 0 otherwise.

In this case the country experiences a large depreciation without a major loss in international reserves. This indicator is more relevant for the case of floating exchange rate countries, where changes in international reserves are usually minimal.

I computed a number of two-way frequency tables similar to table 7 using both crisis definitions and both definitions of current account reversals. I also performed $\chi^{2}$ tests for independence of occurrence of these phenomena. Table 8 presents data on the shares of current account reversals of both types that are accompanied by crises. Results are presented for the same three samples as above: large countries, industrial countries, and all countries, under three different lag structures (no lag between reversal and crisis, crisis lagged one period, and crisis lagged two periods into the reversal). ${ }^{52}$ The results suggest that, historically, current account reversals and currency crises have occurred jointly in a large proportion of cases. Consider, for example, the case of crisis type A and reversal type I for the sample of large countries: 26.7 percent of countries with a type I reversal experienced a contemporaneous type A crisis; 43.1 percent experienced such a crisis in the second year of the reversal episode; and 34.5 percent of the reversals were accompanied by a crisis in the third (and final) year of the reversal episode. Table 8 also shows that industrial countries with reversals tended to experience currency crises during the initial year of the reversal episode. The table also reports p-values for $\chi^{2}$ tests of the independence of reversals and currency crises; in most cases the null hypothesis that the two are independent is rejected at conventional levels.

52. Data on the percentage of crises that also correspond to reversals are available from the author on request. The results of the $\chi^{2}$ tests confirm those discussed above. I also used GDP distributions for other years to define large countries and obtained similar results. 
Table 8. Incidence of Current Account Reversal Associated with Currency Crisis ${ }^{\mathrm{a}}$ Percent of countries with reversal episodes

\begin{tabular}{|c|c|c|c|c|c|c|}
\hline \multirow[b]{2}{*}{$\begin{array}{l}\text { Type of reversal and } \\
\text { country sample }\end{array}$} & \multicolumn{2}{|c|}{$\begin{array}{c}\text { Reversal and } \\
\text { crisis are } \\
\text { contemporaneous }\end{array}$} & \multicolumn{2}{|c|}{$\begin{array}{l}\text { Crisis follows } \\
\text { reversal by } \\
\text { one year }\end{array}$} & \multicolumn{2}{|c|}{$\begin{array}{l}\text { Crisis follows } \\
\text { reversal by } \\
\text { two years }\end{array}$} \\
\hline & $\begin{array}{l}\text { Type A } \\
\text { crisis }\end{array}$ & $\begin{array}{l}\text { Type B } \\
\text { crisis }\end{array}$ & $\begin{array}{l}\text { Type A } \\
\text { crisis }\end{array}$ & $\begin{array}{l}\text { Type B } \\
\text { crisis }\end{array}$ & $\begin{array}{l}\text { Type A } \\
\text { crisis }\end{array}$ & $\begin{array}{c}\text { Type B } \\
\text { crisis }\end{array}$ \\
\hline \multicolumn{7}{|l|}{ Type I reversal } \\
\hline Large countries & $\begin{array}{l}26.7 \\
(0.09)\end{array}$ & $\begin{array}{l}16.1 \\
(0.01)\end{array}$ & $\begin{array}{l}43.1 \\
(0.00)\end{array}$ & $\begin{array}{l}17.2 \\
(0.00)\end{array}$ & $\begin{array}{l}34.5 \\
(0.00)\end{array}$ & $\begin{array}{l}13.8 \\
(0.05)\end{array}$ \\
\hline Industrial countries & $\begin{array}{l}6.7 \\
(0.49)\end{array}$ & $\begin{array}{l}0.0 \\
(0.43)\end{array}$ & $\begin{array}{l}25.0 \\
(0.16)\end{array}$ & $\begin{array}{l}12.5 \\
(0.10)\end{array}$ & $\begin{array}{l}50.0 \\
(0.00)\end{array}$ & $\begin{array}{l}12.5 \\
(0.11)\end{array}$ \\
\hline All countries & $\begin{array}{l}21.2 \\
(0.10)\end{array}$ & $\begin{array}{l}9.1 \\
(0.38)\end{array}$ & $\begin{array}{l}25.6 \\
(0.00)\end{array}$ & $\begin{array}{l}10.3 \\
(0.08)\end{array}$ & $\begin{array}{l}22.2 \\
(0.01)\end{array}$ & $\begin{array}{l}9.8 \\
(0.09)\end{array}$ \\
\hline \multicolumn{7}{|l|}{ Type II reversal } \\
\hline Large countries & $\begin{array}{l}31.2 \\
(0.00)\end{array}$ & $\begin{array}{l}18.2 \\
(0.00)\end{array}$ & $\begin{array}{l}42.9 \\
(0.00)\end{array}$ & $\begin{array}{l}15.6 \\
(0.00)\end{array}$ & $\begin{array}{l}29.5 \\
(0.01)\end{array}$ & $\begin{array}{l}12.8 \\
(0.04)\end{array}$ \\
\hline Industrial countries & $\begin{array}{l}28.6 \\
(0.09)\end{array}$ & $\begin{array}{l}14.3 \\
(0.07)\end{array}$ & $\begin{array}{l}35.7 \\
(0.01)\end{array}$ & $\begin{array}{c}0.0 \\
(0.43)\end{array}$ & $\begin{array}{l}26.7 \\
(0.11)\end{array}$ & $\begin{array}{l}6.7 \\
(0.67)\end{array}$ \\
\hline All countries & $\begin{array}{l}20.2 \\
(0.05)\end{array}$ & $\begin{array}{l}10.0 \\
(0.03)\end{array}$ & $\begin{array}{l}23.8 \\
(0.00)\end{array}$ & $\begin{array}{l}11.5 \\
(0.00)\end{array}$ & $\begin{array}{l}16.7 \\
(0.86)\end{array}$ & $\begin{array}{l}8.2 \\
(0.47)\end{array}$ \\
\hline
\end{tabular}

Source: Author's calculations using data from World Bank, World Development Indicators, various years. a. Numbers in parentheses are p-values of the $\chi^{2}$ test.

Table 9 presents data on the distribution of exchange rate changes for countries with type I current account reversals. ${ }^{53}$ The top panel reports results for the nominal exchange rate (relative to the dollar; here a positive number indicates a depreciation), and the bottom panel for the tradeweighted RER index. These changes are calculated as the cumulative exchange rate change for the period from three years before the reversal to the year of the reversal. For comparison I have also included the distribution of three-year nominal exchange rate changes for a control group of countries that did not experience a current account reversal during 1970-2001. The results in the top panel indicate that countries experiencing reversals have tended to have significantly larger nominal depreciations than the control group. Consider, for example, the case of large countries: the average depreciation associated with a reversal episode in

53. Data on countries experiencing type II reversals are not reported here, but the results are similar and are available from the author on request. 
Table 9. Mean Cumulative Changes in Exchange Rates Following Type I Current Account Reversals ${ }^{\mathrm{a}}$

Percent

\begin{tabular}{lccc}
\hline Country sample & $\begin{array}{c}\text { Countries } \\
\text { experiencing } \\
\text { type I reversal }\end{array}$ & $\begin{array}{c}\text { Countries not } \\
\text { experiencing } \\
\text { reversal }\end{array}$ & $\begin{array}{c}\text { Kruskal-Wallis test } \\
(p \text {-value })^{b}\end{array}$ \\
\hline $\begin{array}{l}\text { Nominal exchange rate } \\
\text { Large countries }\end{array}$ & 33.1 & 9.2 & 0.00 \\
Industrial countries & 18.9 & 3.2 & 0.19 \\
All countries & 27.5 & 9.5 & 0.00 \\
Real exchange rate & & & \\
Large countries & -1.4 & 0.04 & 0.12 \\
Industrial countries & 9.3 & 1.6 & 0.55 \\
All countries & -4.0 & 3.6 & 0.00 \\
\hline
\end{tabular}

Source: Author's calculations.

a. Data are cumulative changes over the three years beginning with the year of the current account reversal.

b. The null hypothesis is that the data from the two samples have been drawn from the same population.

c. A positive number indicates a real appreciation.

those countries that suffered reversals is 33 percent versus only 9.2 percent for the control group. To test formally whether the nominal exchange rate behaved differently in reversal and control countries, I performed a series of nonparametric Kruskal-Wallis $\chi^{2}$ tests on the equality of the distribution of the cumulative depreciation. The null hypothesis is that the data for the reversal countries and those for the control group have been drawn from the same population. As table 9 shows, in the majority of cases (two out of three) the null hypothesis is rejected at conventional levels.

The bottom panel of table 9 presents data for the cumulative change in the RER for the reversal and the control groups. Large countries experienced a rather small real depreciation on average (1.4 percent) in the period surrounding a current account adjustment, a result that is not statistically different from that for the control group $(\mathrm{p}=.12)$. For the complete sample the $\chi^{2}$ test indicates that the treatment and the control groups are drawn from different populations. Perhaps surprisingly, for the industrial countries the cumulative average change in the RER is an appreciation, not a depreciation.

The average accumulated depreciations (both nominal and real) in the reversal countries reported in table 9 are very small compared with the "required" depreciations calculated in a number of studies, includ- 
ing the simulations reported earlier in this paper. Obstfeld and Rogoff, ${ }^{54}$ for example, estimate that eliminating the U.S. current account deficit would require a real depreciation of between 16 and 36 percent. Blanchard, Giavazzi, and Sa have done estimates that indicate a required depreciation of the trade-weighted dollar of 40 percent or more. ${ }^{55}$ One of many possible reasons for these differences is that the United States is a very large country, whereas the countries that have experienced reversals are much smaller. Also, the elasticities may be different for the United States than for the average reversal country. Yet another possibility has to do with the level of economic activity and aggregate demand. Most recent models of the U.S. current account assume that the economy stays on a full-employment path. It is possible, however, that countries that have experienced reversals have also gone through economic slowdowns, and that a reduction in aggregate demand contributed to the adjustment effort.

\section{The Probability of Experiencing a Current Account Reversal}

To better understand the forces behind current account reversals, I estimated a number of equations on the probability of experiencing a reversal, using panel data and the following empirical model:

$$
\begin{gathered}
\rho_{j t}=\left\{\begin{array}{r}
1, \text { if } \rho_{j t}^{*}>0 \\
0, \text { otherwise. }
\end{array}\right. \\
\rho_{j t}^{*}=\alpha \omega_{j t}+\varepsilon_{j t} .
\end{gathered}
$$

Variable $\rho_{j t}$ takes a value of 1 if country $j$ experienced a current account reversal in period $t$, and zero if it did not. Whether the country experiences a current account reversal is assumed to be the result of an unobserved latent variable $\rho_{j t}^{*}$, which in turn is assumed to depend linearly on vector $\omega_{j t}$. The error term $\varepsilon_{j t}$ is given by a variance component model: $\varepsilon_{j t}=v_{j}+\mu_{j t}$, where $v_{j}$ is independent and identically distributed (i.i.d.) with zero mean and variance $\sigma_{v}^{2}$ and $\mu_{j t}$ is normally distributed with zero mean and variance $\sigma_{\mu}^{2}=1$. The data set used covers eighty-seven countries for the 1970-2000 period; data are not available for every country for every

54. Obstfeld and Rogoff (2004).

55. Blanchard, Giavazzi, and Sa (this volume). 
year, however. See appendix table A-3 for exact definitions and data sources.

In determining the specification of this probit model, I followed the literature on external crises and included the following covariates: ${ }^{56}$ the oneyear-lagged ratio of the current account deficit to GDP; a "sudden stop" dummy that takes the value of 1 if the country experienced a sudden stop in capital inflows in the previous year; an index of the occurrence of sudden stops in the same region in the same year (to capture the effect of regional contagion); the one-year-lagged ratio of gross external debt to GDP $;{ }^{57}$ the one-year-lagged rate of growth of domestic credit; the oneyear-lagged ratio of the country's fiscal deficit to GDP; and the logarithm of the country's initial GDP per capita. The regressions were performed with and without the fiscal deficit variable for both measures of current account reversal.

Table 10 presents the results of estimating this variance-component probit model for a sample of large countries, defined as before. The vast majority of the coefficients have the expected sign, and most are significant at conventional levels. The results may be summarized as follows: A larger current account deficit increases the probability of a reversal in the following year, as does a sudden stop of capital inflows. Countries with higher GDP per capita have a lower probability of a reversal. The results do not provide strong support for the contagion hypothesis: the variable that measures the incidence of sudden stops in the county's region is significant in only one of the four equations (although its sign is always positive). There is evidence that an increase in a country's gross external debt increases the likelihood of a reversal, and that larger public sector deficits increase the probability of a type II reversal. Countries with looser monetary policy, as measured by growth in domestic credit, also have a higher probability of experiencing a reversal. Although the United States is a very special case, the results reported in table 10 provide some support for the idea that, during the last few years, the probability of the United States experiencing a current account reversal has increased. Indeed, the United States has experienced a steady increase in some important determinants

56. See, for example, Frankel and Rose (1996), Milesi-Ferretti and Razin (2000), and Edwards (2002).

57. Ideally, one would want to have data for net debt; however, data on net liabilities are unavailable for most countries. 
Table 10. Probability of Current Account Reversals in Large Countries:

Random-Effects Probit Regressions ${ }^{\mathrm{a}}$

\begin{tabular}{|c|c|c|c|c|}
\hline \multirow[b]{2}{*}{ Independent variable ${ }^{b}$} & \multicolumn{2}{|c|}{ Type I reversal } & \multicolumn{2}{|c|}{ Type II reversal } \\
\hline & $10-1$ & $10-2$ & $10-3$ & $10-4$ \\
\hline $\begin{array}{l}\text { Ratio of current account deficit } \\
\text { to GDP }\end{array}$ & $\begin{array}{l}0.05 \\
(1.65)^{*}\end{array}$ & $\begin{array}{l}0.05 \\
(1.63)^{*}\end{array}$ & $\begin{array}{l}0.19 \\
(5.46) * * *\end{array}$ & $\begin{array}{l}0.19 \\
(5.53)^{* * * *}\end{array}$ \\
\hline $\begin{array}{l}\text { Occurrence of sudden stop } \\
\text { in country }\end{array}$ & $\begin{array}{l}0.82 \\
(2.06) * *\end{array}$ & $\begin{array}{l}0.83 \\
(2.08)^{* *}\end{array}$ & $\begin{array}{l}0.93 \\
(2.46)^{* *}\end{array}$ & $\begin{array}{l}0.83 \\
(2.24)^{* *}\end{array}$ \\
\hline Index of sudden stops in region & $\begin{array}{c}0.78 \\
(0.66)\end{array}$ & $\begin{array}{c}0.80 \\
(0.68)\end{array}$ & $\begin{array}{c}1.42 \\
(1.54)\end{array}$ & $\begin{array}{l}1.64 \\
(1.84)^{*}\end{array}$ \\
\hline Ratio of external debt to GDP & $\begin{array}{l}0.01 \\
(2.81)^{* * *}\end{array}$ & $\begin{array}{l}0.01 \\
(2.88) * * *\end{array}$ & $\begin{array}{r}0.001 \\
(0.29)\end{array}$ & $\begin{array}{r}0.001 \\
(0.32)\end{array}$ \\
\hline Domestic credit growth & $\begin{array}{l}0.001 \\
(2.50)^{* *}\end{array}$ & $\begin{array}{l}0.001 \\
(2.52)^{* *}\end{array}$ & $\begin{array}{c}0.0002 \\
(1.65)^{*}\end{array}$ & $\begin{array}{l}0.0003 \\
(1.71)^{*}\end{array}$ \\
\hline Ratio of fiscal deficit to GDP & $\begin{array}{c}-0.004 \\
(0.12)\end{array}$ & & $\begin{array}{l}0.05 \\
(1.85)^{*}\end{array}$ & \\
\hline Initial GDP per capita & $\begin{array}{l}-0.28 \\
(2.19) * *\end{array}$ & $\begin{array}{l}-0.29 \\
(2.23)^{* *}\end{array}$ & $\begin{array}{l}-0.15 \\
(1.57)\end{array}$ & $\begin{array}{l}-0.16 \\
(1.66)^{*}\end{array}$ \\
\hline No. of observations & 545 & 582 & 557 & 597 \\
\hline No. of countries & 36 & 37 & 36 & 37 \\
\hline
\end{tabular}

Source: Author's regressions.

a. Results obtained from estimating the model in equations 13 and 14 in the text on unbalanced panel data for the sample of large countries. Numbers in parentheses are $z$ statistics (in absolute value); all equations include country dummy variables, results for which are not reported. Asterisks indicate statistical significance at the $* * * 1$ percent, $* * 5$ percent, and $* 10$ percent levels.

b. All independent variables are lagged one period.

of reversals, such as its gross international debt, its fiscal deficit, and the current account deficit itself.

\section{Current Account Reversals and Growth}

I investigate next the relationship between current account reversals and real economic performance, with particular attention to the following issues: whether, historically, abrupt current account adjustments have had an effect on GDP growth; whether sudden stops and current account reversals have had similar impacts on growth; and whether the effects of reversals depend on the structural characteristics of the country in question, including its economic size, its openness to trade, and the extent to which it restricts capital mobility. In addressing these issues, I emphasize the case of large countries; as a comparison, however, I also provide results for the complete sample of large and small countries.

Previous analyses of the real effects of current account reversals have reached different conclusions. Milesi-Ferretti and Razin, for example, 
used before-and-after analyses as well as cross-country regressions to address this issue, concluding that "reversal events seem to entail substantial changes in macroeconomic performance between the period before and the period after the crisis but are not systematically associated with a growth slowdown." 58 On the other hand, in a previous paper I used dynamic panel regression analysis and concluded that major current account reversals had a negative effect on investment, and that they had "a negative effect on GDP per capita growth, even after controlling for investment." 59

GROWTH EFFECTS OF CURRENT ACCOUNT REVERSALS AND SUDDEN STOPS: AN ECONOMETRIC MODEL. The point of departure for the empirical analysis is a two-equation formulation for the dynamics of real growth of GDP per capita in country $j$ in period $t$. Equation 15 is the long-run GDP growth equation, and equation 16 captures the growth dynamics:

$$
\begin{gathered}
\tilde{g}_{j}=\alpha+x_{j} \beta+r_{j} \theta+\omega_{j} . \\
\Delta g_{j t}=\lambda\left[\tilde{g}_{j}-g_{j t-1}\right]+\varphi v_{j t}+\gamma u_{j t}+\varepsilon_{j t} .
\end{gathered}
$$

I use the following notation: $\tilde{g}_{j}$ is the long-run rate of real growth in GDP per capita in country $j$; $x_{j}$ is a vector of structural, institutional, and policy variables (identified below) that determine long-run growth; $r_{j}$ is a vector of regional dummies; $\alpha, \beta$, and $\theta$ are parameters to be estimated; and $\omega_{j}$ is an error term assumed to be heteroskedastic. In equation $16, g_{j t}$ is the rate of growth of GDP per capita in country $j$ in period $t$. The terms $v_{j t}$ and $u_{j t}$ are shocks, assumed to have zero mean and finite variance and to be mutually uncorrelated. Specifically, $v_{j t}$ is assumed to be an external terms-of-trade shock, whereas $u_{j t}$ captures other shocks, including current account reversals and sudden stops of capital inflows. $\varepsilon_{j t}$ is an error term, which is assumed to have a variance component form, and $\lambda$, $\varphi$, and $\gamma$ are parameters that determine the particular characteristics of the growth process. Equation 16 has the form of an equilibrium correction model and states that the actual rate of growth in period $t$ will deviate from the long-run rate of growth because of the existence of three types of shocks: $v_{j t}, u_{j t}$, and $\varepsilon_{j t}$. Over time, however, the actual rate of growth will tend to

58. Milesi-Ferretti and Razin (2000, p. 303, emphasis added).

59. Edwards (2002, p. 52). In a recent paper, Guidotti, Villar, and Sturzenegger (2003) consider the role of openness in an analysis of import and export behavior in the aftermath of a reversal. See also Frankel and Cavallo (2004). 
converge toward its long-run value, with the rate of convergence given by $\lambda$. Parameter $\varphi$ in equation 16 is expected to be positive, indicating that an improvement in the terms of trade will result in a (temporary) acceleration in the rate of growth, and that negative terms-of-trade shocks are expected to have a negative effect on $g_{j t}{ }^{60}$ From the perspective of the present analysis, a key issue is whether current account reversals and sudden stops reduce growth; that is, whether coefficient $\gamma$ is significantly negative. In estimating equation 16 I used dummy variables for sudden stops and reversals. An important question, addressed in detail below, is whether the effects of different shocks on growth are different for countries with different structural characteristics, such as the degree of trade and capital account openness.

Equations 15 and 16 are estimated using a two-step procedure. In the first step I estimate the long-run growth equation 15 using a cross-country data set. These data are averages for 1974-2001, and the estimation corrects for heteroskedasticity. These first-stage estimates are then used to generate long-run predicted growth rates to replace $\tilde{g}_{j}$ in the equilibrium error correction model (equation 16). In the second step I estimate equation 16 using the generalized least squares (GLS) method for unbalanced panels; I use both random effects and fixed effects estimation procedures (only the former are reported here). The data are annual data for 157 countries for 1970-2000; data are not available for every country for every year, however. (See appendix table A-3 for exact data definitions and sources.)

In estimating equation 15, I followed the standard literature on growth, as summarized by Robert Barro and Xavier Sala-i-Martin, Jeffrey Sachs and Andrew Warner, and David Dollar, among others. ${ }^{61} \mathrm{I}$ assume that the long-run rate of growth of GDP $\tilde{g}_{j}$ depends on a number of structural, policy, and social variables: the equation includes the logarithm of initial GDP per capita, the investment ratio, the secondary education coverage rate (as a proxy for human capital), an index of the degree of openness of the economy to trade and capital flows, the ratio of government consumption to GDP, and regional dummies. The results obtained from these first-stage estimates are not reported but are available upon request.

60. See Edwards and Levy-Yeyati (forthcoming) for details.

61. Barro and Sala-i-Martin (1995); Sachs and Warner (1995); Dollar (1992). 
Table 11 presents the results of the second-stage estimation of the growth dynamics equation (equation 16), using random effects. The top panel reports results for the sample of large countries, and the bottom panel for the complete sample. The equations whose results are reported in columns 11-1 and 11-2 include the type I and type II reversal dummies, respectively. Column 11-3 includes the sudden stops indicator and neither reversal dummy. Columns 11-4 and 11-5 include both the sudden stops indicator and the type I or the type II reversal variable, respectively, as regressors. ${ }^{62}$

The results in table 11 may be summarized as follows: The estimated coefficient on the growth gap is, as expected, positive, significant, and smaller than 1. The estimates are on the high side (between 0.66 and 0.72 ), suggesting that, on average, deviations between long-run and actual growth get eliminated rather quickly. For instance, according to the results in column 11-1, approximately 85 percent of a shock to real growth in GDP per capita will be eliminated within three years. Also, as expected, the estimated coefficients on the terms-of-trade shock are always positive and statistically significant, indicating that an improvement in the terms of trade results in an acceleration, and a deterioration in a deceleration, in the rate of growth of real GDP per capita. As may be seen from columns 11-1 and 11-2, the coefficients on both the current account reversal variables are significantly negative, indicating that reversals result in a deceleration of growth. For large countries these results suggest that, on average, a type I reversal is associated with a reduction of GDP growth by 2.1 percentage points. This effect is eliminated gradually as $g$ converges toward $\tilde{g}_{j}$. In the case of type II reversals, the estimated negative effect on GDP growth is even larger, at -4.1 percentage points. The results in column 11-3 show that countries that have experienced a sudden stop of capital inflows have also tended to experience a reduction in GDP growth: for large countries the point estimate is -2.4 percentage points. This is the case whether or not the country in question has also suffered a current account reversal. The equations reported in the last two columns in table 11 include both the current account reversal (type I or type II) and sudden stop indicators. The results in column 11-5 suggest that higher costs of adjustment have been

62. In the analysis that follows, and in order to focus the discussion, I concentrate on the effects of current account reversals. 
Table 11. Impact of Current Account Reversals and Sudden Stops on Economic Growth: Random-Effects GLS Regressions ${ }^{\mathrm{a}}$

\begin{tabular}{|c|c|c|c|c|c|}
\hline $\begin{array}{l}\text { Sample and } \\
\text { independent variable }\end{array}$ & $11-1$ & $11-2$ & $11-3$ & $11-4$ & $11-5$ \\
\hline \multicolumn{6}{|l|}{ Large countries } \\
\hline Growth gap ${ }^{\mathrm{b}}$ & $\begin{array}{c}0.67 \\
(21.20)^{* * *}\end{array}$ & $\begin{array}{c}0.72 \\
(25.33) * * *\end{array}$ & $\begin{array}{c}0.68 \\
(22.82)^{* * * *}\end{array}$ & $\begin{array}{c}0.66 \\
(20.54)^{* * *}\end{array}$ & $\begin{array}{c}0.71 \\
(24.60) * * *\end{array}$ \\
\hline $\begin{array}{l}\text { Change in terms of } \\
\text { trade }\end{array}$ & $\begin{array}{l}0.09 \\
(7.88) * * *\end{array}$ & $\begin{array}{c}0.10 \\
(10.30)^{* * *}\end{array}$ & $\begin{array}{l}0.08 \\
(7.99) * * *\end{array}$ & $\begin{array}{l}0.08 \\
(7.34)^{* * * *}\end{array}$ & $\begin{array}{l}0.10 \\
(9.52) * * *\end{array}$ \\
\hline $\begin{array}{l}\text { Type I current } \\
\text { account reversal }\end{array}$ & $\begin{array}{l}-2.12 \\
(3.94) * * *\end{array}$ & & & $\begin{array}{l}-2.11 \\
(3.89) * * *\end{array}$ & \\
\hline $\begin{array}{l}\text { Type II current } \\
\text { account reversal }\end{array}$ & & $\begin{array}{l}-4.13 \\
(9.34) * * *\end{array}$ & & & $\begin{array}{l}-3.74 \\
(7.94) * * *\end{array}$ \\
\hline $\begin{array}{l}\text { Sudden stop of } \\
\text { capital inflows }\end{array}$ & & & $\begin{array}{l}-2.36 \\
(3.99) * * *\end{array}$ & $\begin{array}{l}-2.39 \\
(3.99)^{* * * *}\end{array}$ & $\begin{array}{l}-1.37 \\
(2.36)^{* *}\end{array}$ \\
\hline Constant & $\begin{array}{l}-0.28 \\
(2.10)^{* *}\end{array}$ & $\begin{array}{l}-0.21 \\
(1.70)^{*}\end{array}$ & $\begin{array}{l}-0.31 \\
(2.36) * *\end{array}$ & $\begin{array}{c}-0.18 \\
(1.36)\end{array}$ & $\begin{array}{c}-0.18 \\
(1.39)\end{array}$ \\
\hline No. of observations & 799 & 846 & 811 & 764 & 810 \\
\hline No. of countries & 41 & 41 & 41 & 41 & 41 \\
\hline Adjusted $R^{2}$ & 0.41 & 0.50 & 0.45 & 0.42 & 0.50 \\
\hline \multicolumn{6}{|l|}{ All countries } \\
\hline Growth gap ${ }^{\mathrm{b}}$ & $\begin{array}{c}0.82 \\
(40.26)^{* * *}\end{array}$ & $\begin{array}{c}0.82 \\
(42.10)^{* * * *}\end{array}$ & $\begin{array}{c}0.81 \\
(40.18)^{* * * *}\end{array}$ & $\begin{array}{c}0.82 \\
(38.93)^{* * *}\end{array}$ & $\begin{array}{c}0.82 \\
(40.76)^{* * * *}\end{array}$ \\
\hline $\begin{array}{l}\text { Change in terms of } \\
\text { trade }\end{array}$ & $\begin{array}{l}0.07 \\
(11.77)^{* * *}\end{array}$ & $\begin{array}{c}0.08 \\
(12.65)^{* * *}\end{array}$ & $\begin{array}{c}0.07 \\
(11.31)^{* * *}\end{array}$ & $\begin{array}{c}0.07 \\
(11.10)^{* * *}\end{array}$ & $\begin{array}{c}0.08 \\
(12.18)^{* * *}\end{array}$ \\
\hline $\begin{array}{l}\text { Type I current } \\
\text { account reversal }\end{array}$ & $\begin{array}{l}-1.04 \\
(3.00)^{* * *}\end{array}$ & & & $\begin{array}{l}-0.73 \\
(2.03)^{* *}\end{array}$ & \\
\hline $\begin{array}{l}\text { Type II current } \\
\text { account reversal }\end{array}$ & & $\begin{array}{l}-2.01 \\
(6.64) * * *\end{array}$ & & & $\begin{array}{l}-1.80 \\
(5.50) * * *\end{array}$ \\
\hline $\begin{array}{l}\text { Sudden stop of } \\
\text { capital inflows }\end{array}$ & & & $\begin{array}{l}-1.23 \\
(2.82) * * *\end{array}$ & $\begin{array}{l}-1.02 \\
(2.28)^{* *}\end{array}$ & $\begin{array}{c}-0.53 \\
(1.19)\end{array}$ \\
\hline Constant & $\begin{array}{l}-0.30 \\
(2.26)^{* *}\end{array}$ & $\begin{array}{c}-0.15 \\
(1.16)\end{array}$ & $\begin{array}{l}-0.27 \\
(2.62) * * *\end{array}$ & $\begin{array}{l}-0.26 \\
(2.33)^{* *}\end{array}$ & $\begin{array}{c}-0.14 \\
(1.32)\end{array}$ \\
\hline No. of observations & 1,723 & 1,821 & 1,641 & 1,546 & 1,635 \\
\hline No. of countries & 90 & 90 & 81 & 81 & 81 \\
\hline Adjusted $R^{2}$ & 0.48 & 0.49 & 0.51 & 0.52 & 0.51 \\
\hline
\end{tabular}

Source: Author's regressions.

a. Results obtained from estimating the model in equations 15 and 16 in the text on unbalanced panel data. The dependent variable is the change in the growth rate of GDP per capita (in percentage points). Numbers in parentheses are $t$ statistics (in absolute value); all regressions include country dummy variables, results for which are not reported. Asterisks indicate statistical significance at the $* * *$ 1 percent, ** 5 percent, and $* 10$ percent levels.

b. Difference between estimated long-run and actual annual growth rates of real GDP, in percentage points.

associated with type II reversals: the coefficient on the type II dummy variable is more than twice as large (in absolute terms) as that on the sudden stop variable in the same equation. According to this equation, countries that have experienced both a reversal and a sudden stop experienced, 
on average, a decline in growth in GDP per capita of 5.1 percentage points.

To summarize, the results presented in table 11 are revealing and cast some light on the likely costs of a future current account reversal in the United States. Historically, large countries that have suffered such reversals have experienced deep reductions in GDP growth. These estimates indicate that, on average, and with other factors unchanged, the decline in growth in GDP per capita has been in the range of 2.1 to 4.1 percentage points in the first year of the adjustment. Three years after the initial adjustment, GDP growth will still be below its long-run trend.

EXTENSIONS, ENDOGENEITY, AND ROBUSTNESS. Here I discuss some extensions of the model and examine the robustness of the estimates, including possible endogeneity bias. Specifically, I address the role of countries' structural characteristics in determining the costs of adjustment, present results from instrumental variables GLS regressions with random effects, and consider the effects of changes in the terms of trade.

Openness and the costs of adjustment. Recent studies on the economics of external adjustment have emphasized the role of openness to trade. Guillermo Calvo, Alejandro Izquierdo, and Luís-Fernando Mejia, Frankel and Cavallo, and I, among others, have found that countries that are more open to international trade tend to incur a lower cost of adjustment to a current account reversal. ${ }^{63}$ These studies, however, do not distinguish between large and small countries or between openness in the trade account and openness in the capital account. To investigate whether openness has historically affected the cost of external adjustment in large countries, I added two interactive regressors to equation 16: the first interacts the reversal indicator with trade openness, and the second with an index of the country's degree of international capital mobility. Trade openness is proxied by the fitted value of the ratio of imports plus exports to GDP obtained from a gravity model of bilateral trade. ${ }^{64}$ The index on international capital mobility is one that I developed in a previous paper, ${ }^{65}$ the index ranges from 0 to 100, with higher numbers denoting greater capital mobility. The results, presented in table 12, show that the coefficients

63. Calvo, Izquierdo, and Mejia (2004); Frankel and Cavallo (2004); Edwards (2004).

64. The use of gravity trade equations to generate instruments in panel estimation was pioneered by Jeffrey Frankel. See, for example, Frankel and Cavallo (2004).

65. Edwards (forthcoming). 
Table 12. Impact of Trade Openness and Capital Mobility on Growth in Large Countries: Random-Effects GLS Regressions ${ }^{\mathrm{a}}$

\begin{tabular}{|c|c|c|c|c|}
\hline Independent variable & $12-1$ & $12-2$ & $12-3$ & $12-4$ \\
\hline Growth gap ${ }^{\mathrm{b}}$ & $\begin{array}{c}0.67 \\
(21.17)^{* * *}\end{array}$ & $\begin{array}{c}0.67 \\
(21.12)^{* * *}\end{array}$ & $\begin{array}{c}0.68 \\
(22.35)^{* * *}\end{array}$ & $\begin{array}{c}0.68 \\
(22.40)^{* * *}\end{array}$ \\
\hline Change in terms of trade & $\begin{array}{l}0.09 \\
(7.78)^{* * *}\end{array}$ & $\begin{array}{l}0.09 \\
(7.83)^{* * *}\end{array}$ & $\begin{array}{l}0.09 \\
(8.77)^{* * *}\end{array}$ & $\begin{array}{l}0.09 \\
(8.79)^{* * *}\end{array}$ \\
\hline Type I current account reversal & $\begin{array}{l}-3.48 \\
(1.98) * *\end{array}$ & $\begin{array}{l}-3.84 \\
(4.42) * * *\end{array}$ & & \\
\hline $\begin{array}{l}\text { Type I current account reversal } \times \\
\text { trade openness indicator }\end{array}$ & $\begin{array}{l}0.27 \\
(2.47)^{* *}\end{array}$ & $\begin{array}{l}0.27 \\
(2.55)^{* *}\end{array}$ & & \\
\hline $\begin{array}{l}\text { Type I current account reversal } \times \\
\text { capital mobility indicator }\end{array}$ & $\begin{array}{r}-0.007 \\
(0.24)\end{array}$ & & & \\
\hline Type II current account reversal & & & $\begin{array}{l}-1.92 \\
(1.83)^{*}\end{array}$ & $\begin{array}{l}-4.12 \\
(7.94) * * *\end{array}$ \\
\hline $\begin{array}{l}\text { Type II current account reversal } \times \\
\text { trade openness indicator }\end{array}$ & & & $\begin{array}{c}-0.02 \\
(0.58)\end{array}$ & $\begin{array}{c}-0.04 \\
(1.27)\end{array}$ \\
\hline $\begin{array}{l}\text { Type II current account reversal } \times \\
\text { capital mobility indicator }\end{array}$ & & & $\begin{array}{l}-0.05 \\
(1.70)^{*}\end{array}$ & \\
\hline Constant & $\begin{array}{l}-0.28 \\
(2.14)^{* *}\end{array}$ & $\begin{array}{l}-0.29 \\
(2.19) * *\end{array}$ & $\begin{array}{c}-0.16 \\
(1.26)\end{array}$ & $\begin{array}{c}-0.16 \\
(1.27)\end{array}$ \\
\hline No. of observations & 794 & 793 & 793 & 793 \\
\hline No. of countries & 41 & 41 & 41 & 41 \\
\hline Adjusted $R^{2}$ & 0.38 & 0.38 & 0.43 & 0.43 \\
\hline
\end{tabular}

Source: Author's regressions.

a. Results obtained from estimating the model in equations 15 and 16 in the text on unbalanced panel data, with the addition of the variables interacting current account reversals with trade openness and capital mobility indicators. The dependent variable is the change in the growth rate of GDP per capita (in percentage points). Numbers in parentheses are $t$ statistics (in absolute value); all regressions include country dummy variables, results for which are not reported. Asterisks indicate statistical significance at the $* * * 1$ percent, $* * 5$ percent, and $* 10$ percent levels.

b. Difference between estimated long-run and actual annual growth rates of real GDP, in percentage points.

on the reversal indicators continue to be significantly negative, as they were in table 11. The coefficient that interacts trade openness with the presence of a type I reversal is significantly positive in columns $12-1$ and $12-2$ in table 12 . The point estimate in both is 0.27 , indicating that external adjustment is less costly in countries with higher trade ratios. However, the coefficient that interacts trade openness and the dummy for reversals is not significant when the type II reversal indicator is used. The coefficient that interacts capital account openness and reversal is not significant in any of the regressions.

Endogeneity and instrumental variables estimates. The results discussed above were obtained using a random-effects GLS procedure for unbalanced panels, and under the assumption that the reversal variable is exogenous. However, whether a reversal takes place may be affected by 
the country's growth performance, and thus endogenously determined. To deal with this issue I reestimated equation 16 using an instrumental variables GLS panel procedure. The following instruments were used: the one- and two-period-lagged ratio of the current account deficit to GDP; a lagged sudden stop dummy, which takes the value of 1 if the country experienced a sudden stop in the previous year; the same regional contagion variable used in the previous analysis; the one-year-lagged ratio of external gross debt to GDP; the one-year-lagged ratio of net international reserves to GDP; the one-year-lagged rate of growth of domestic credit; and the logarithm of initial GDP per capita. As the results in table 13 show, the coefficients on the reversal indicators are significantly negative, confirming that, historically, current account reversals have had an adverse effect on growth. The absolute values of the estimated coefficients, however, are larger than those obtained with the random-effects GLS procedure (top panel of table 11).

Terms-of-trade effects. The estimation that yielded the results in table 11 controlled for terms-of-trade changes. That is, the coefficients on the type I and II reversal variables capture the effect of a current account reversal with the terms of trade held constant. As discussed above, however, external adjustment in large countries is very likely to affect the terms of trade. The exact nature of that effect will depend on a number of factors, including the relevant elasticities and the extent of home bias in consumption. To get an idea of the effect of current account reversals when international prices are allowed to adjust, I reestimated equation 16 excluding the terms-of-trade variable for the sample of large countries. The full results are not reported here, but the estimated coefficients on the reversal variables were smaller in absolute terms than those in table 11: -2.43 versus -2.12 in table 11 for type I reversals, and -3.63 versus -4.13 for type II reversals. These results suggest that, for this sample, external adjustment has been associated, on average, with an improvement in the international terms of trade.

Robustness tests and other extensions. To test the robustness of the results, I also estimated several alternative versions of equation 16 for the sample of large countries. In one of these exercises I introduced lagged values of the reversal indicators as additional regressors. The results (not reported here) indicated that lagged values of these indexes were not significant at conventional levels. I also varied the definition of "large countries," but this likewise did not dramatically affect the results. 
Table 13. Impact of Current Account Reversals on Growth in Large Countries: Instrumental Variables Regressions ${ }^{\mathrm{a}}$

\begin{tabular}{lcc}
\hline Independent variable & $13-1$ & $13-2$ \\
\hline Growth gap $^{\mathrm{b}}$ & 0.86 & 0.89 \\
& $(18.50)^{* * *}$ & $(20.50)^{* * *}$ \\
Change in terms of trade & 0.06 & 0.11 \\
& $(3.87)^{* * *}$ & $(6.86)^{* * *}$ \\
Type I current account reversal & -9.40 & \\
& $(4.55)^{* * *}$ & -12.24 \\
Type II current account reversal & & $(7.40)^{* * *}$ \\
& & 0.38 \\
Constant & 0.24 & $(1.95)^{*}$ \\
No. of observations & $(1.27)$ & 538 \\
No. of countries & 514 & 34 \\
Adjusted $R^{2}$ & 34 & 0.40 \\
\hline
\end{tabular}

Source: Author's regressions.

a. Results obtained from estimating the model in equations 15 and 16 in the text on unbalanced panel data using an instrumental variables GLS procedure. The instruments used were the one- and two-period-lagged ratio of the current account deficit to GDP; a lagged sudden stop dummy equal to 1 if the country experienced a sudden stop in the previous year; the regional sudden stop index used in table 10; the one-year-lagged ratio of external gross debt to GDP; the one-year-lagged ratio of net international reserves to GDP; the one-year-lagged rate of growth of domestic credit; and the logarithm of initial GDP per capita. Numbers in parentheses are $t$ statistics (in absolute value); all regressions include country dummy variables, results for which are not reported. Asterisks indicate statistical significance at the $* * * 1$ percent, $* * 5$ percent, and $* 10$ percent levels.

b. Difference between estimated long-run and actual annual growth rates of real GDP, in percentage points.

\section{Concluding Remarks}

The results reported in this paper illustrate the uniqueness of the current U.S. external situation. Never before in modern economic history has a large industrial country run persistent current account deficits of the magnitude posted by the United States since 2000. This development can be explained in the context of a portfolio model of the current account, where, for a number of reasons - the end of the Cold War, the Internet revolution, and the liberalization of international capital movements in most countries-foreign investors have increased their (net) demand for U.S. assets. Indeed, by increasing their holdings of U.S. assets to 30 percent of their wealth, foreigners have provided American residents with sufficient funds to run the large current account deficits of the last few years.

The future of the U.S. current account-and thus of the dollardepends on whether foreign investors will continue to add U.S. assets to their investment portfolios. As a way of sharpening the discussion, I have deliberately made a very optimistic assumption, namely, that during the 
next five years foreigners' net holdings of U.S. assets, as a proportion of U.S. GDP, will double from their current level. The simulation model indicates that, even under this optimistic assumption, in the not-toodistant future the United States is likely to go through a significant external adjustment. Indeed, one cannot rule out a scenario in which the U.S. current account deficit shrinks abruptly by 3 to 6 percent of GDP. According to the simulations, this type of adjustment would imply a cumulative real depreciation of the trade-weighted dollar in the range of 13 to 23 percent during the first three years of the adjustment.

To obtain an idea of the possible consequences of this type of adjustment, I analyzed the international evidence on current account reversals. The results of this empirical investigation indicate that major current account reversals have been associated with large declines in GDP growth: In large countries, with other factors unchanged, the decline in growth in GDP per capita has averaged in the range of 2.1 to 4.1 percentage points in the first year of the adjustment. Three years after the initial adjustment, GDP growth is still below its long-run trend.

The results presented in this paper are revealing and suggest that the United States is likely to experience a major adjustment in the not-toodistant future. However, many questions are still unresolved and will require additional research. These include the following:

- How does the behavior of foreign central banks, including their future demand for U.S. assets, affect the likelihood and magnitude of a U.S. current account reversal? A particularly important question involves the appropriate international reserves policy for central banks in a world where most exchange rates have at least some flexibility. A number of analysts are concerned that the Asian central banks will reduce their demand for U.S. assets, unleashing an abrupt collapse in the value of the dollar.

- How exactly does the adjustment process work in large countries? Although I have concentrated on a group of countries that I defined as "large," in fact all of the countries in my sample that have experienced current account reversals have much smaller economies than the United States. In particular, more analysis is needed of the consequences for global interest rates of a major U.S. current account adjustment.

- How do nominal exchange rates behave in a current account adjustment episode? Most models of the U.S. current account imbalance, including the portfolio model presented here, have focused on the RER. 
However, estimating the way in which the adjustment process will affect nominal exchange rates is not a trivial matter. The actual adjustment in nominal exchange rates will depend on pass-through coefficients, as well as on the exchange rate policies followed by some important U.S. trade partners, including China, Japan, and other Asian countries.

-Finally, how does private sector saving, and in particular household saving, behave in the United States? To the extent that household saving increases - as a result of a decline in home prices, for instance-the current account deficit will decline without putting pressure on the value of the dollar. Likewise, if saving in foreign countries declines, the current account surplus in the rest of the world will also tend to decline, helping to achieve global balance. Of course, what matters for current account behavior is aggregate national saving. Therefore the behavior of public sector saving is a fundamental variable for future current account and real exchange rate behavior in the United States and the rest of the world. 


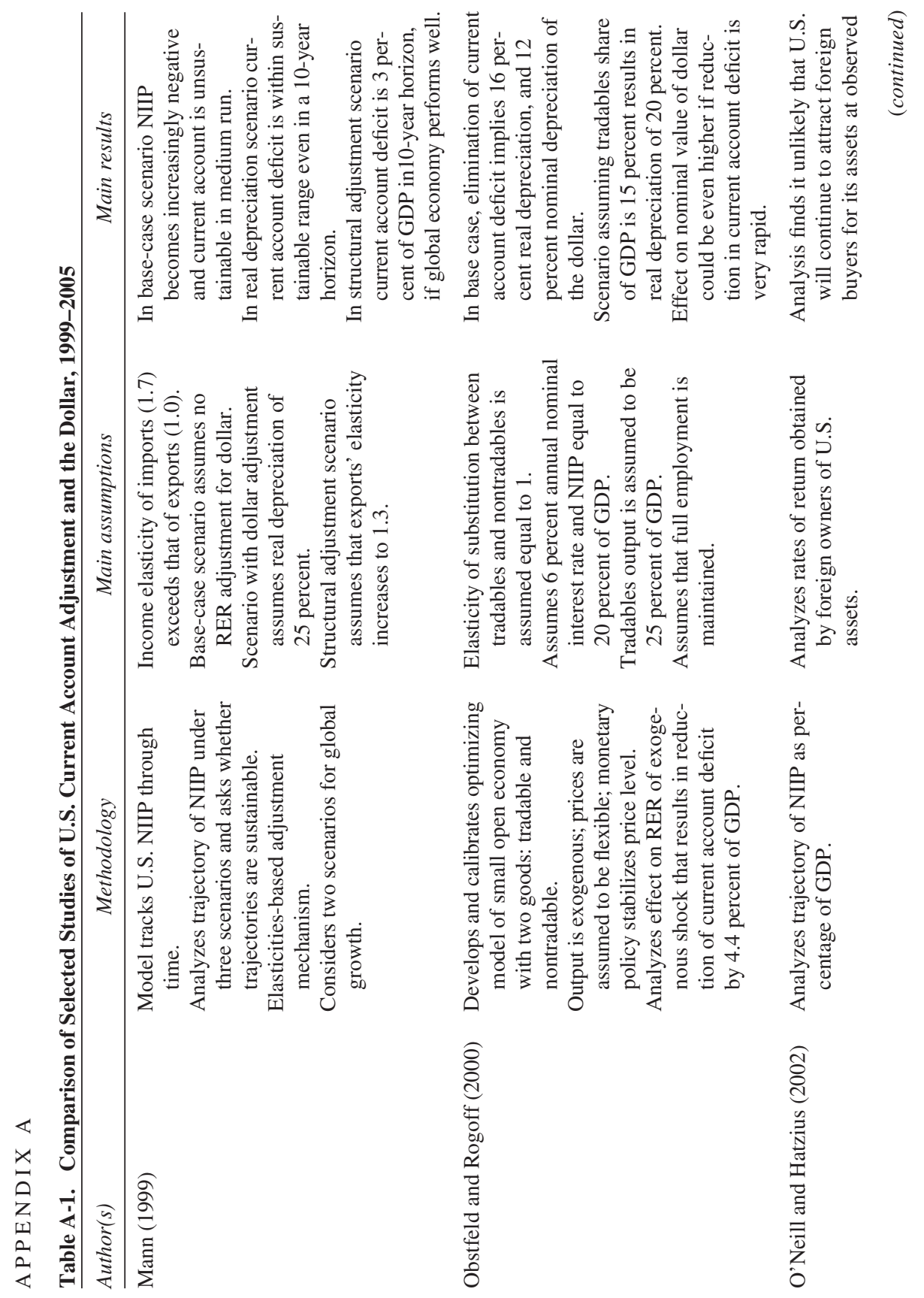




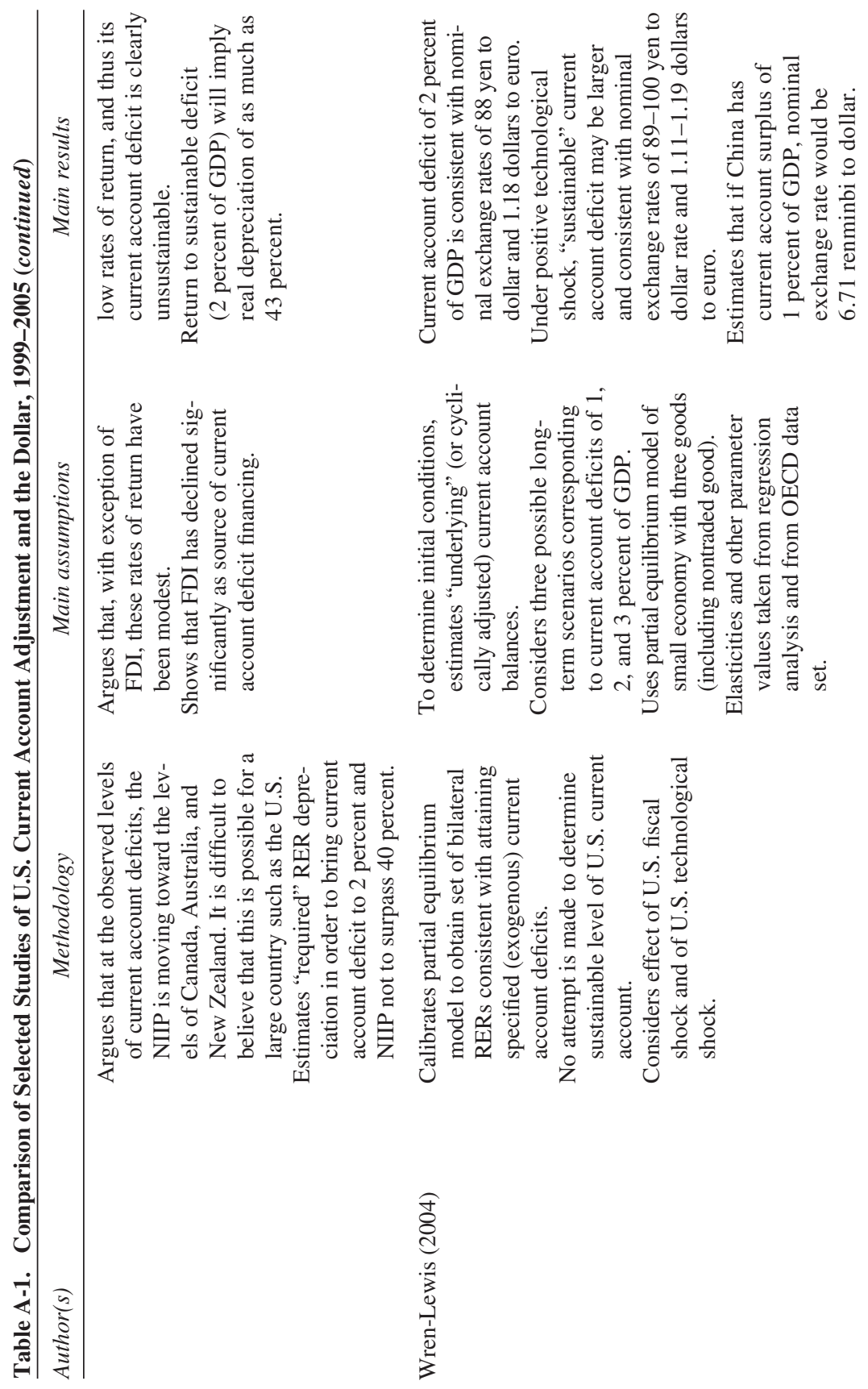



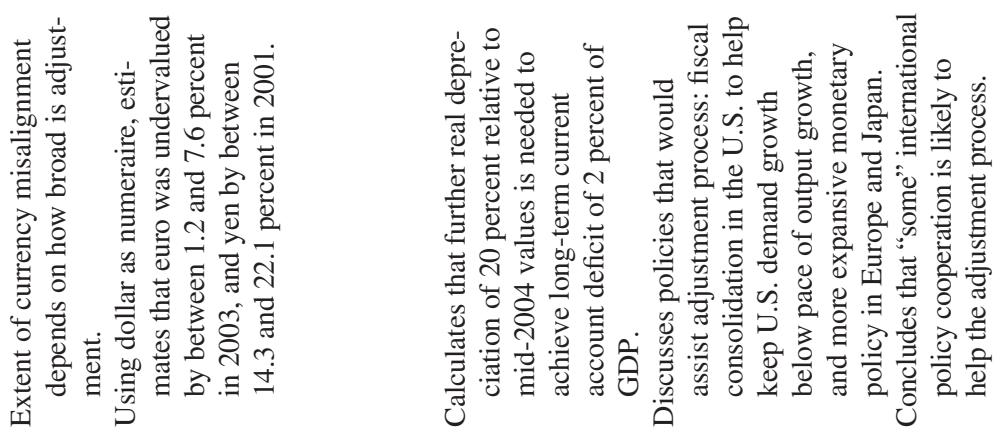

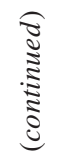
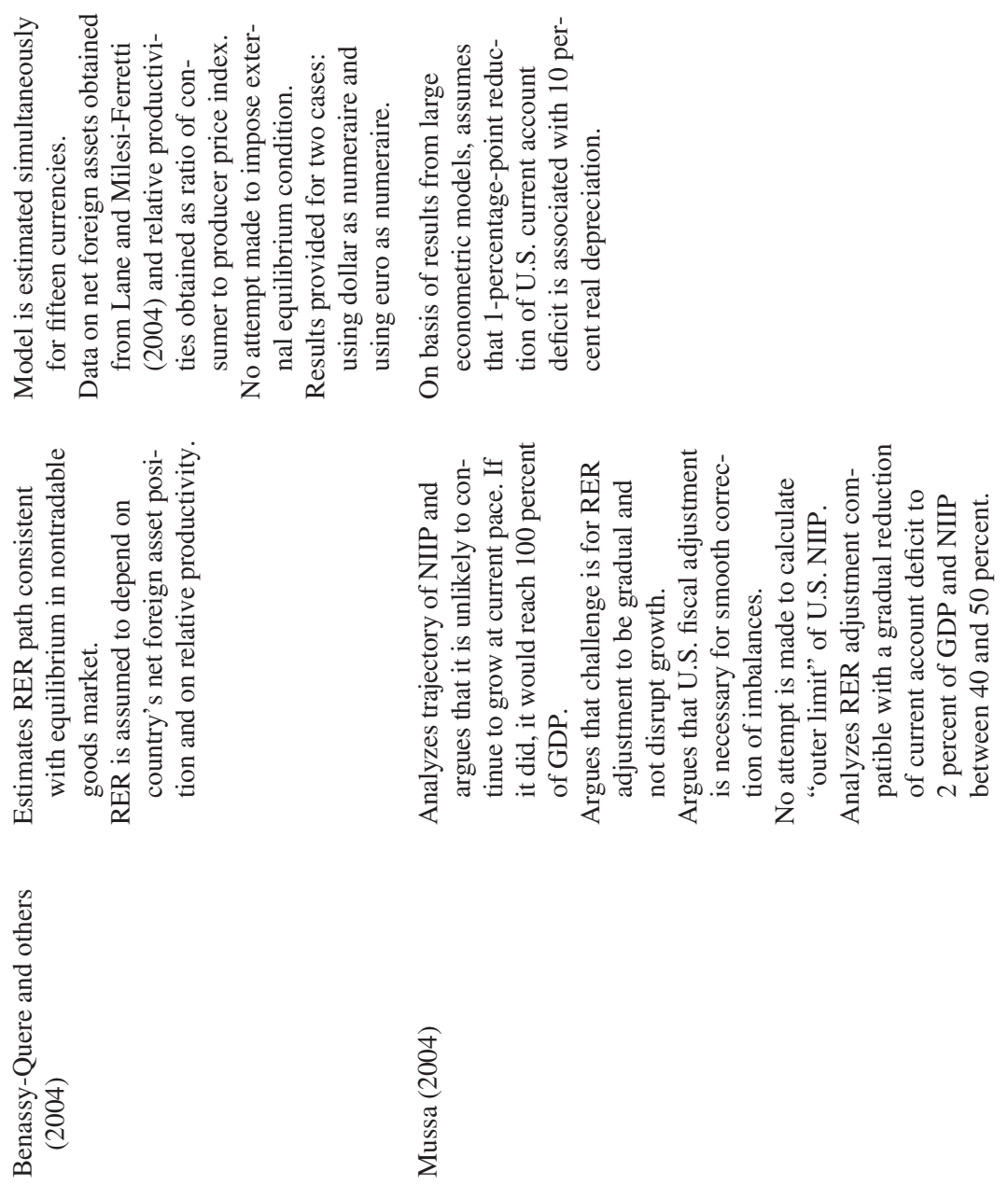

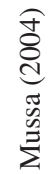




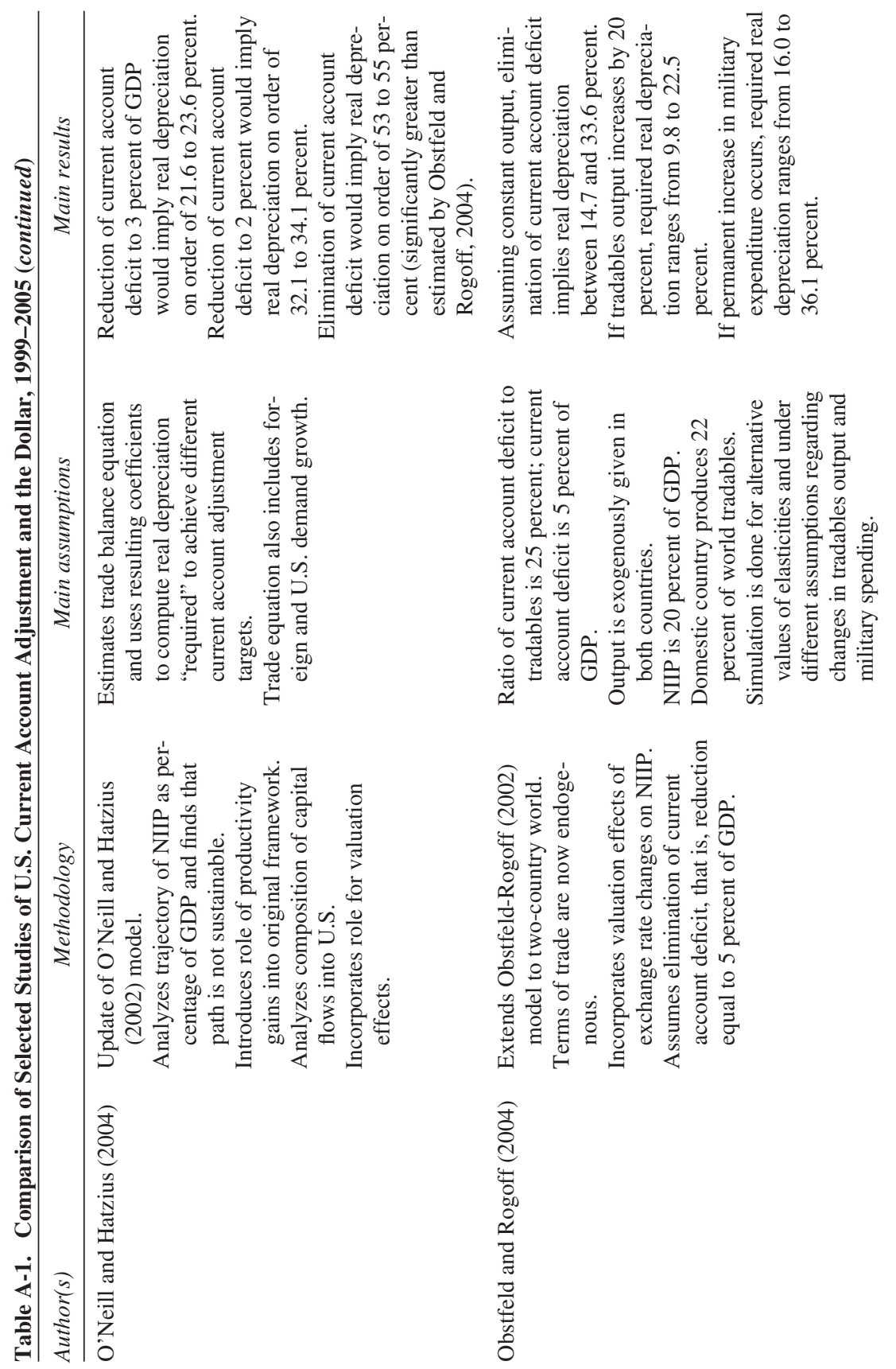




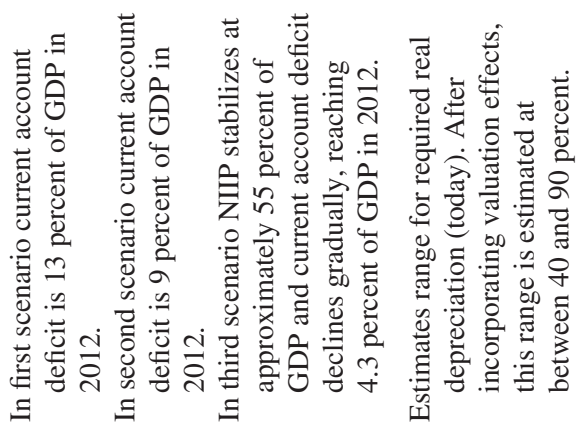

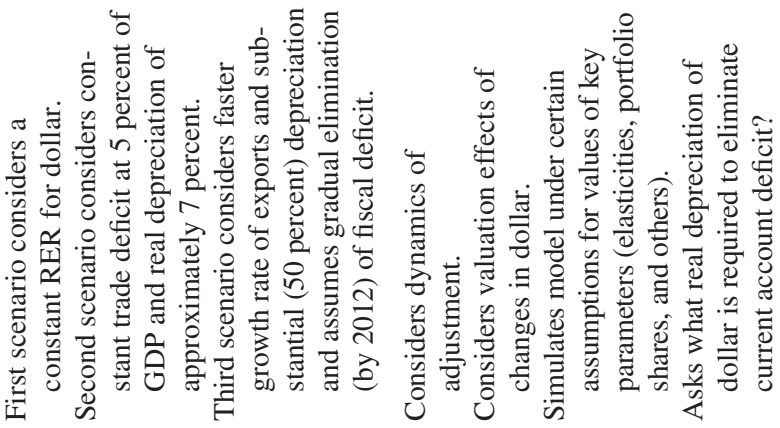
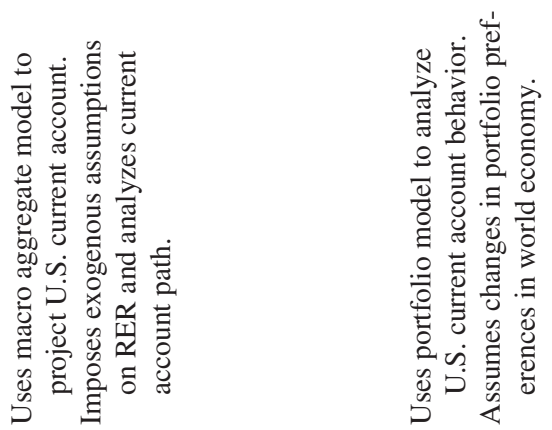

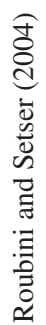

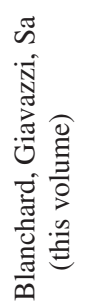


Table A-2. Parameter Values for Variables Used in the Simulations

\begin{tabular}{|c|c|c|}
\hline Variable & $\begin{array}{l}\text { Parameter } \\
\text { value }\end{array}$ & Definition and comments \\
\hline \multicolumn{3}{|c|}{ Portfolio adjustment model } \\
\hline$W_{\text {Initial }}^{\text {World }}$ & $\$ 80$ trillion & World wealth in 2005 \\
\hline$W_{\text {Initial }}^{\text {US }}$ & $\$ 36$ trillion & U.S. wealth in 2005 \\
\hline$\alpha_{\text {initial }}$ & 0.300 & $\begin{array}{l}\text { Foreigners' demand for U.S. assets in (early) } \\
2005^{\mathrm{a}}\end{array}$ \\
\hline$\alpha_{j j, \text { initial }}$ & 0.730 & $\begin{array}{l}\text { U.S. residents' demand for U.S. assets in } \\
\text { (early) } 2005\end{array}$ \\
\hline$\alpha_{\text {final }}$ & 0.400 & $\begin{array}{l}\text { Foreigners' portfolio allocation to U.S. assets } \\
\text { in } 2010 \text {. An alternative simulation } \\
\text { assumes that, after reaching } 0.40, \alpha \\
\text { declines gradually to } 0.365 \text { in } 2014 \text {. }\end{array}$ \\
\hline$\alpha_{j j, \text { final }}$ & 0.710 & $\begin{array}{l}\text { U.S. residents' demand for U.S. assets in } \\
\text { (early) } 2010 \text {. An alternative simulation } \\
\text { assumes that, after reaching } 0.71, \alpha_{j j} \text { rises } \\
\text { to } 0.72 \text { in } 2014 \text {. }\end{array}$ \\
\hline$\alpha_{\text {historical }}$ & 0.205 & $\begin{array}{l}\text { Foreigners' demand for U.S. assets in (early) } \\
\text { 1996. The move to the "initial" current value } \\
\text { of } 0.30 \text { is assumed to have been gradual. }\end{array}$ \\
\hline$\alpha_{j j, \text { historical }}$ & 0.800 & $\begin{array}{l}\text { U.S. residents' demand for U.S. assets in } \\
\text { (early) } 1996\end{array}$ \\
\hline$\lambda$ & 3.0 & Wealth-to-GDP ratio \\
\hline$\gamma_{\text {initial }}^{*}$ & 0.290 & $\begin{array}{l}\text { Value of }\left[\alpha \theta-\left(1-\alpha_{j j}\right)\right] \lambda \text { in (early) } 2005 \\
\quad(\text { see text })\end{array}$ \\
\hline$\gamma_{\text {final }}^{*}$ & 0.600 & Value of $\left[\alpha \theta-\left(1-\alpha_{j j}\right)\right] \lambda$ in 2010 \\
\hline$\gamma_{\text {historical }}^{*}$ & 0.150 & Value of $\left[\alpha \theta-\left(1-\alpha_{j j}\right)\right] \lambda$ in 1996 \\
\hline \multicolumn{3}{|c|}{ Transfer problem } \\
\hline$g$ & 0.03 & $\begin{array}{l}\text { Assumed long-term sustainable annual rate of } \\
\text { growth of U.S. GDP }\end{array}$ \\
\hline$g^{*}$ & 0.03 & $\begin{array}{l}\text { Annual growth rate of rest-of-world GDP } \\
\text { (including emerging economies as well as } \\
\text { Europe and Japan) }\end{array}$ \\
\hline$\pi$ & 0.023 & Long-term annual rate of U.S. inflation \\
\hline$\pi^{*}$ & 0.023 & $\begin{array}{l}\text { Long-term annual rate of foreign inflation; } \\
\text { some simulations used a value of } 0.03 \text {. }\end{array}$ \\
\hline$i$ & 0.043 & $\begin{array}{l}\text { Long-term real U.S. interest rate; some simula- } \\
\text { tions used a value in the range } 0.05 \text { to } 0.065 \text {. }\end{array}$ \\
\hline$i^{*}$ & 0.053 & $\begin{array}{l}\text { Long-term real rest-of-world interest rate; } \\
\text { some simulations used values in the range } \\
0.06 \text { to } 0.075 \text {. }\end{array}$ \\
\hline$\eta_{e}$ & -1.10 & $\begin{array}{l}\text { Price elasticity of U.S. imports; this is } \\
\text { slightly below the consensus value; a range } \\
\text { of values was used in other simulations. }\end{array}$ \\
\hline
\end{tabular}


Table A-2. Parameter Values for Variables Used in the Simulations (continued)

\begin{tabular}{|c|c|c|}
\hline Variable & $\begin{array}{l}\text { Parameter } \\
\text { value }\end{array}$ & Definition and comments \\
\hline$\varepsilon_{e}$ & 0.50 & $\begin{array}{l}\text { Real exchange rate elasticity of U.S. exports } \\
\text { (approximately the consensus value); sensi- } \\
\text { tivity analyses used a range of } 0.2 \text { to } 0.6 \text {. } \\
\text { Consensus value for income elasticity of U.S. } \\
\text { imports }\end{array}$ \\
\hline$\varepsilon_{y}$ & 1.50 & $\begin{array}{l}\text { Consensus value for income elasticity of U.S. } \\
\text { exports }\end{array}$ \\
\hline$\sigma_{m}$ & 1.20 & $\begin{array}{l}\text { Share of imports as a fraction of U.S. GDP in } \\
2004\end{array}$ \\
\hline & 0.14 & Share of exports in U.S. GDP in 2004 \\
\hline $\begin{array}{l}\sigma_{x} \\
\hat{p}_{m}^{*}\end{array}$ & $\begin{array}{l}0.09 \\
0\end{array}$ & $\begin{array}{l}\text { Rate of change in world price of imports; in } \\
\text { alternative simulations a range of }-0.05 \text { to } \\
-0.10 \text { was used. }\end{array}$ \\
\hline$\hat{p}_{x}^{*}$ & 0 & $\begin{array}{l}\text { Rate of change in world price of exports; in } \\
\text { alternative simulations a range of } 0.05 \text { to } \\
0.07 \text { was used. }\end{array}$ \\
\hline$\psi$ & 0.30 & $\begin{array}{l}\text { Coefficient measuring rate of adjustment } \\
\text { from actual to demanded asset stock; value } \\
\text { chosen to obtain best possible fit for } \\
\text { 1996-2004. }\end{array}$ \\
\hline$\kappa$ & 0.20 & $\begin{array}{l}\text { Coefficient measuring rate of adjustment of } \\
\text { absorption to change in income; value cho- } \\
\text { sen to obtain best possible fit for } \\
\text { 1996-2004 period. }\end{array}$ \\
\hline
\end{tabular}

Source: Author's model described in the text.

a. The adjustment period for $\alpha$ and $\alpha_{i j}$ is assumed to be five years. 
Table A-3. Variable Definitions and Data Sources

\begin{tabular}{|c|c|c|}
\hline Variable & Definition & Source \\
\hline $\begin{array}{l}\text { Type I current account } \\
\text { reversal }\end{array}$ & $\begin{array}{l}\text { Reduction in an existing cur- } \\
\text { rent account deficit by at } \\
\text { least } 6 \text { percent of GDP } \\
\text { over three years. }\end{array}$ & $\begin{array}{l}\text { Author's determination based } \\
\text { on data from World Bank, } \\
\text { World Development Indi- } \\
\text { cators, various years }\end{array}$ \\
\hline $\begin{array}{l}\text { Type II current account } \\
\text { reversal }\end{array}$ & $\begin{array}{l}\text { Reduction in an existing cur- } \\
\text { rent account deficit by at } \\
\text { least } 4 \text { percent of GDP in } \\
\text { one year }\end{array}$ & $\begin{array}{l}\text { Author's determination based } \\
\text { on data from World Bank, } \\
\text { World Development Indi- } \\
\text { cators, various years }\end{array}$ \\
\hline Sudden stop & $\begin{array}{l}\text { Reduction in net capital } \\
\text { inflows by at least } 5 \text { per- } \\
\text { cent of GDP in one year. } \\
\text { The country must have } \\
\text { received an inflow of cap- } \\
\text { ital larger than its region's } \\
\text { third quartile during the } \\
\text { preceding two years. }\end{array}$ & $\begin{array}{l}\text { Author's determination based } \\
\text { on data from World Bank, } \\
\text { World Development Indi- } \\
\text { cators, various years }\end{array}$ \\
\hline Type A currency crisis & $\begin{array}{l}\text { Dummy variable equal to } 1 \\
\text { when an index of external } \\
\text { pressures exceeds its mean } \\
\text { by } 3 \text { standard deviations }\end{array}$ & $\begin{array}{l}\text { Author's determination based } \\
\text { on international reserves } \\
\text { and nominal exchange rate } \\
\text { data from International } \\
\text { Monetary Fund, Interna- } \\
\text { tional Financial Statistics, } \\
\text { various years }\end{array}$ \\
\hline Type B currency crisis & $\begin{array}{l}\text { Dummy variable equal to } 1 \\
\text { when an index of external } \\
\text { pressures exceeds its mean } \\
\text { by } 3 \text { standard deviations } \\
\text { exclusively through } \\
\text { changes in the nominal } \\
\text { exchange rate }\end{array}$ & $\begin{array}{l}\text { Author's determination based } \\
\text { on nominal exchange rate } \\
\text { data from International } \\
\text { Monetary Fund, Interna- } \\
\text { tional Financial Statistics, } \\
\text { various years }\end{array}$ \\
\hline Nominal exchange rate & $\begin{array}{l}\text { Dollars per local currency } \\
\text { unit }\end{array}$ & $\begin{array}{l}\text { International Monetary Fund, } \\
\text { International Financial } \\
\text { Statistics, various years }\end{array}$ \\
\hline Real exchange rate & $\begin{array}{l}\text { Bilateral real exchange rate } \\
\text { calculated using consumer } \\
\text { price indexes in both } \\
\text { countries }\end{array}$ & $\begin{array}{l}\text { Author's calculations using } \\
\text { nominal exchange rate and } \\
\text { consumer price index data } \\
\text { from International Mone- } \\
\text { tary Fund, International } \\
\text { Financial Statistics }\end{array}$ \\
\hline
\end{tabular}

(continued) 
Table A-3. Variable Definitions and Data Sources (continued)

\begin{tabular}{lcc}
\hline Variable & \multicolumn{1}{c}{ Definition } & Source \\
\hline Change in terms of trade & $\begin{array}{c}\text { Change in capacity to } \\
\text { import for a given amount } \\
\text { of exports, in terms of } \\
\text { constant local currency }\end{array}$ & $\begin{array}{c}\text { World Bank, World Develop- } \\
\text { ment Indicators }\end{array}$ \\
Ratio of reserves to GDP & $\begin{array}{c}\text { Net international reserves } \\
\text { divided by GDP }\end{array}$ & $\begin{array}{c}\text { World Bank, World Develop- } \\
\text { ment Indicators }\end{array}$ \\
Domestic credit growth & $\begin{array}{c}\text { Growth rate of domestic } \\
\text { credit in percent a year }\end{array}$ & $\begin{array}{c}\text { World Bank, World Develop- } \\
\text { ment Indicators }\end{array}$ \\
Ratio of external debt to & $\begin{array}{c}\text { Total external debt divided } \\
\text { by GDP }\end{array}$ & $\begin{array}{c}\text { World Bank, World Develop- } \\
\text { ment Indicators }\end{array}$ \\
Ratio of fiscal deficit to & $\begin{array}{c}\text { Overall government budget } \\
\text { deficit divided by GDP }\end{array}$ & $\begin{array}{c}\text { World Bank, World Develop- } \\
\text { ment Indicators }\end{array}$ \\
GDP & $\begin{array}{c}\text { Real GDP per capita in 1995 } \\
\text { dollars }\end{array}$ & $\begin{array}{c}\text { World Bank, World Develop- } \\
\text { ment Indicators }\end{array}$ \\
Index of capital mobility & $\begin{array}{c}\text { Index from 0 to 100, with } \\
\text { higher values indicating } \\
\text { greater capital mobility }\end{array}$ & $\begin{array}{c}\text { Edwards (forthcoming) } \\
\text { Trade openness indicator }\end{array}$ \\
$\begin{array}{c}\text { Exports plus imports divided } \\
\text { by GDP }\end{array}$ & $\begin{array}{c}\text { World Bank, World Develop- } \\
\text { ment Indicators }\end{array}$ \\
\hline
\end{tabular}




\section{Comments and Discussion}

Kathryn M. E. Dominguez: The U.S. current account deficit at the end of 2004 reached 5 percent of GDP, a remarkably high number and far outside the experience of any other large developed country. This paper by Sebastian Edwards examines the factors that have led to such a large imbalance, attempts to forecast how long deficits of this magnitude can be sustained, and analyzes the likely near-term consequences for the U.S. economy of a reversal of the current account balance.

Current account deficits have been the norm for the United States for some twenty-five years, just as surpluses have been the norm for many developing countries and many of the rest of the world's developed countries. In theory a deficit, even if persistent, is not necessarily cause for concern. A country can finance deficits only if the world perceives it to be a good credit risk. Indeed, the reason many developing countries are forced to run surpluses is that they lack access to deficit financing. So, if the world has been willing to finance U.S. current account deficits for over a quarter of a century, why the concern?

Edwards makes the case that the reason for concern is that the U.S. current account deficit is not sustainable: the world will not be willing to continue to finance U.S. deficits on the current scale into the future. He argues further that, even if net demand for U.S. assets continues to increase, a current account reversal is inevitable, which in turn will result in a significant reduction in U.S. growth. If Edwards's predictions are accurate, the implications for the U.S. economy are quite bleak.

I will begin by discussing some of the underlying factors that have led to the recent large U.S. current account deficits, and which are likely to influence the future path of global imbalances. Next I will raise some disagreements with some of the assumptions made in the portfolio balance 
model used by Edwards to simulate U.S. current account dynamics into the future. I will then discuss whether evidence from smaller countries regarding the links between current account reversals and economic growth is relevant for the U.S. situation. Finally, I will return to Edwards's predictions about the likely downturn for the U.S. economy in light of the evidence from the data and the model.

Edwards's figure 1, which graphs the U.S. current account balance and the dollar real exchange rate since 1973, provides some historical context and shows the close association of dollar appreciations and U.S. current account deficits. His table 1 shows that the sources of financing for these deficits have changed significantly over the past few years. In particular, foreign direct investment and other equity flows, which were important in the 1990s, have been replaced with net fixed-income flows, consisting largely of purchases of U.S. Treasury securities by foreign central banks. This shift in financing has had the favorable consequence (from the point of view of the U.S. income account) of U.S. investors receiving higher returns on the foreign assets they hold than foreigners have received on their U.S. assets. In addition, because the bulk of U.S. liabilities held by foreigners are denominated in dollars, whereas the bulk of foreign assets held by U.S. investors are denominated in foreign currency, the recent dollar depreciation has led to positive valuation effects, which, in turn, have improved the U.S. net international investment position.

An examination of the factors driving the movements in these data is warranted, especially if these factors are expected to persist. In this context it is interesting to contrast the role of exchange rate policies in the 1980s with that in the more recent period. In the mid-1980s several foreign countries joined with the United States in coordinated interventions to bring down the value of the dollar and correct global imbalances. In the more recent period there has been no such coordinated attempt on the part of the United States or the rest of the world to intervene against the dollar. Quite the opposite: central banks in Asian countries have been intervening to support the value of the dollar relative to their own currencies, by building dollar reserves to the tune of about $\$ 2$ trillion. China alone holds around $\$ 610$ billion in dollar reserves and Japan $\$ 840$ billion. Their purchases of low-return U.S. Treasury securities have sustained and indeed amplified global imbalances by serving to both finance the U.S. deficit and maintain a high value of the dollar.

Edwards discusses this role of foreign central banks in sustaining the U.S. deficit in the context of the United States' increasing vulnerability to 
a change in sentiment toward the dollar on the part of these few key players. An alternative view is that, if the Asian central banks come to believe that it is in their best interests to help correct global imbalances, they can look to the policies followed by central banks in the 1980s to help bring about an orderly change in the value of the dollar.

Another issue that is little discussed in the paper, but is clearly a driving force behind the current global imbalances, is differences in economic growth rates. The U.S. economy in the 1990s sustained the longest expansion in its recorded history. At the same time, Europe and Japan largely experienced at best lackluster growth. These growth differentials affected the U.S. current account balance in two ways. First, faster relative U.S. growth led to higher aggregate demand in the United States for both domestic products and imports, relative to foreign demand for U.S. products. Second, because the U.S. economy was booming in both absolute and comparative terms, global investors were attracted to U.S. assets, which in turn helped finance the deficit and maintain a strong dollar. Any future changes in growth differentials are similarly likely to affect the size and sustainability of the U.S. current account deficit.

Edwards's figure 4 shows U.S. investment and saving rates since 1970. What is striking is how different today's saving rates look relative to historical norms. In the past decade and especially in the last few years, the net household saving rate has been unusually low. This, combined with the dramatic fall in net public saving in recent years, has reduced total U.S. saving to its lowest level in a quarter of a century. Investment in recent years has also been relatively low, although well within the range of historical norms during periods of slow growth. A country's current account deficit, of course, equals the difference between saving and investment, and if we believe that the U.S. saving rate will eventually revert to historical norms, this provides additional reason for optimism that the current account deficit will improve.

Edwards introduces a partial equilibrium version of a simple portfolio balance model of the current account to simulate how potential changes in the world's appetite for U.S. assets will influence current account and real exchange rate adjustment. A number of the simplifying assumptions implicit in the model are likely to have important implications for the results. In particular, relative asset allocation shares (the shares of their wealth that foreign and U.S. investors allocate to foreign and domestic assets) are assumed to be exogenously determined and subject to home bias. The model 
is then used to analyze how an exogenous change in these portfolio allocation preferences will influence the current account. In his base-case simulation, Edwards assumes that foreign net holdings of U.S. assets rise to 60 percent of U.S. GDP by 2010 (starting from 30 percent at the end of 2004), that the U.S. economy and the rest of the world economy grow at the same rate, that the U.S. saving rate remains at its current low level, that the income elasticity for U.S. imports is higher than for rest-of-world imports, and that the international terms of trade remain unchanged. The key result is that, even given the assumed doubling in foreign demand for U.S. assets, the U.S. current account deficit will eventually decline to a steady state of 3.2 percent of GDP, with a relatively sharp reversal occurring in 2007, bringing about a 3 percent of GDP reduction in the deficit in three years. The accumulated real dollar depreciation over this period is 22.5 percent.

The virtue of Edwards's model is its simplicity. It allows the reader to easily follow the mechanics of how a change in portfolio preferences influences all the other key variables (net assets held by foreigners, the trade balance, the real exchange rate, and the international wealth transfer associated with these changes). The problem with the model is that its assumptions more or less guarantee the main result, namely, that even with an increase in foreign holdings of U.S. assets, the U.S. current account will experience a sharp reversal. Edwards briefly discusses how a relaxation of some of his assumptions would likely influence (and in most cases soften) his most dire predictions, but the main message remains that a reversal is inevitable.

The final section of the paper uses cross-country evidence to estimate the likely costs of a U.S. current account reversal in terms of growth and employment. The analysis involves examining the incidence of current account reversals since 1970 for various categories of countries, the correlation of reversals and sudden stops in capital inflows, the correlation of reversals and exchange rate changes, and, finally, the correlation of reversals and GDP growth rates. Edwards is candid about a serious problem with this analysis: since the United States is unique both because of its size and because of the role of the dollar in the global economy, it is not clear that the cross-country evidence marshaled here has any relevance for the United States. Indeed, Edwards finds no historical examples of large countries that have experienced a large current account reversal along the lines predicted by his portfolio balance model. 
Yet the statistical information provided is interesting in its own right, even if its relevance to the U.S. experience is uncertain. The international evidence suggests that current account reversals, especially when combined with sudden stops in capital inflows, result in significant reductions in rates of GDP growth. It is certainly hard to argue that a dramatic fall in the current account deficit could occur without major economic dislocation in any country, including the United States. What is less clear is whether the United States is likely to experience a dramatic current account reversal or a sudden stop in capital inflows. Indeed, the fact that many of the factors driving the large current account deficit are unusual relative to historical (or international) norms suggests that predicting future dynamics based on recent experience may not be appropriate.

Does an exit strategy exist for the United States that would allow it to forestall a sharp current account reversal? This question evokes a whole series of related questions that seem worth considering before coming to any conclusions about the future course of the U.S. economy. How might a rise in U.S. interest rates (which would likely both attract more foreign investment and decrease the U.S. income account) muddy the waters? Might higher interest rates, in turn, influence household saving rates? Will the U.S. government continue to run large budget deficits, and, if so, might U.S. households turn Ricardian and save more? Might an internationally coordinated intervention strategy to gradually lower the value of the dollar work to improve global imbalances? How might an increase in rest-of-world growth rates (or a fall in U.S. growth rates) influence trade and investment patterns?

In summary, Edwards has provided a stimulating paper that argues plausibly that the U.S. current account deficit is both unsustainable and likely to lead to a fall in U.S. economic growth. This conclusion relies on the assumption that many of the key U.S. and foreign macroeconomic variables will continue along their course of the past few years. Time will tell whether or not this assumption is a valid one. Given the rather bleak implications of Edwards's analysis, my hope is that the data prove him wrong.

Pierre-Olivier Gourinchas: Sebastian Edwards has written an ambitious paper on an important topic. The paper starts with a thirty-year perspective on U.S. current account developments. It introduces and calibrates a portfolio balance model designed to help in understanding the developments of recent years. It then uses the model to project the adjustment path for the 
dollar's real exchange rate and the U.S. current account. Finally, it discusses the growth implications of current account adjustment in light of the experience of other countries.

I cannot stress enough the importance of the topic: few macroeconomic questions are as pressing today as that of the sources and the implications of growing world external imbalances, ${ }^{1}$ and few issues are receiving as much attention from academics and policymakers alike. In that respect the paper stands resolutely on the alarmist side of the current debate, claiming that the U.S. external position is not sustainable. Even under optimistic assumptions about foreigners' appetite for U.S. assets, the paper finds, "the [U.S.] current account will have to go through a significant adjustment in the not-too-distant future." This adjustment would not be immediate, but it would be dramatic when it arrives: the benchmark projection finds that the current account deficit first increases to 7.3 percent by 2009, then experiences an abrupt reversal that brings it down to 3.2 percent by about 2018 . Such a reversal in the current account would be accompanied by a sharp real depreciation of the dollar of 22.5 percent once the correction begins. Finally, the paper argues, a current account reversal of this magnitude is also typically associated with a significant slowdown in economic activity.

READING THE TEA LEAVES. The paper starts with a thorough analysis of the buildup in U.S. external imbalances. Like other papers before it, ${ }^{2}$ it emphasizes two important elements of the current situation. First, the source of financing of the current account deficit has shifted away from foreign private investors to foreign central banks, and away from equity and direct investment to fixed-income vehicles, especially U.S. Treasury securities. Second, the deficit has been associated in recent years with a decline in U.S. national saving, especially household and public saving. Since the financing of the deficit by foreign central banks does not reflect market forces, it follows that U.S. households and government are artificially living beyond their means. This interpretation, shared by many commentators, puts the blame squarely on U.S. domestic factors. The willingness of Asian central banks, concerned about the value of their currency against the dollar, to finance the deficits only serves to maintain the gravity-defying properties of the deficits and of the dollar exchange rate and makes the U.S. position more vulnerable.

1. See Rajan (2005).

2. For example, Roubini and Setser (2004). 
Although this is a compelling story, it is possible to construct a different reading of the situation. First, the decline in national saving can be an equilibrium outcome, without any shift in the U.S. saving schedule. In fact, if the main impetus behind the current imbalances were a decline in U.S. saving, those imbalances should be associated with high world real interest rates. This was the case in the early 1980s in the United States, the period of so-called twin deficits.

Yet what do we observe? According to the Federal Reserve, the ten-year yield on Treasury inflation-indexed securities has declined from 2.29 percent in January 2003 to 1.63 percent in February 2005. An appealing solution to what has become known as Greenspan's conundrum was put forth by Federal Reserve Governor Ben Bernanke. ${ }^{3}$ He observes that the combination of large deficits and low real interest rates could be the result of a shift in the net saving schedule of the rest of the world, through either reduced foreign investment or increased foreign saving (the saving glut hypothesis). This shift could be a consequence perhaps of the recent current account reversals in Asia as well as the growth slowdown in Europe.

It is also instructive to analyze the sources of financing of the U.S. deficits. As mentioned above, a common interpretation, shared by this paper, is that the current account is increasingly financed through reserve accumulations. I want to argue that the picture is quite different when one considers gross flows together with net flows (table 1). Edwards emphasizes that net foreign direct investment and equity flows for the United States turned negative in 2003-04. Hence the net financing had to have come from net reserves and net debt accumulation. Yet consider gross equity and direct investment liability flows in the table. After a decline between 2000 and 2003 , these flows increased again in 2004 , from $\$ 37.3$ billion to $\$ 56.2$ billion for equities and from $\$ 39.9$ billion to $\$ 115.5$ billion for direct investment. What this means is that the negative net flows come from the larger U.S. gross purchases of equity ( $\$ 93$ billion in 2004) and direct investment ( $\$ 248.5$ billion). The increase in gross U.S. foreign liabilities totaled $\$ 1.4$ trillion in 2004. This total capital inflow helped finance a $\$ 666$ billion current account deficit and $\$ 818$ billion in foreign asset acquisition by U.S. investors (with a $\$ 52$ billion statistical discrepancy). There is really no meaningful way in which the $\$ 358$ billion in net reserve accumulation has to have served to finance the current account deficit. One could just as accurately

\section{Bernanke (2005).}


Table 1. Net and Gross Financial Flows of the United States

Billions of dollars ${ }^{\mathrm{a}}$

\begin{tabular}{lrrrrrrr}
\hline Item & 1998 & 1999 & 2000 & 2001 & 2002 & 2003 & 2004 \\
\hline Reserves, net & -26.7 & 52.3 & 42.5 & 23.1 & 110.3 & 250.1 & 358.1 \\
Foreign private purchases of & 28.6 & 44.5 & -70.0 & -14.4 & 100.4 & 113.4 & 108.1 \\
$\quad$ U.S. Treasuries & & & & & & & \\
Currency & 16.6 & 22.4 & 5.3 & 23.8 & 21.5 & 16.6 & 14.8 \\
Securities, net & 32.1 & 182.6 & 338.0 & 309.2 & 301.4 & 178.6 & 323.2 \\
$\quad$ Debt, gross assets & 22.8 & 1.9 & 15.2 & -24.5 & -33.5 & -28.1 & -2.2 \\
$\quad$ Debt, gross liabilities & 110.7 & 185.9 & 267.4 & 274.4 & 229.3 & 213.7 & 357.9 \\
$\quad$ Net debt & 87.8 & 184.0 & 252.2 & 298.9 & 262.8 & 241.8 & 360.0 \\
$\quad$ Equity, gross assets & 101.4 & 114.3 & 106.7 & 109.1 & 17.6 & 100.4 & 93.0 \\
$\quad$ Equity, gross liabilities & 45.6 & 112.9 & 192.5 & 119.5 & 56.2 & 37.3 & 56.2 \\
$\quad$ Net equity & -55.7 & -1.4 & 85.8 & 10.4 & 38.6 & -63.2 & -36.8 \\
Foreign direct & 36.4 & 64.5 & 162.1 & 24.7 & -62.4 & -133.9 & -133.0 \\
$\quad$ investment, net & & & & & & & \\
$\quad$ Assets & 142.6 & 224.9 & 159.2 & 142.3 & 134.8 & 173.8 & 248.5 \\
$\quad$ Liabilities & 179.0 & 289.4 & 321.3 & 167.0 & 72.4 & 39.9 & 115.5 \\
Claims reported by & -15.1 & -21.5 & 31.9 & 57.6 & 32.6 & 55.1 & -41.5 \\
$\quad$ nonbanks, net & & & & & & & \\
Claims reported & 4.2 & -22.0 & -31.7 & -7.5 & 66.1 & 65.2 & -15.6 \\
$\quad$ by banks, net & & & & & & & \\
Other & -1.2 & -2.1 & -1.8 & -1.6 & -0.9 & -2.5 & -0.2 \\
$\quad$ Net financing & 75.0 & 231.7 & 476.3 & 415.0 & 569.0 & 542.7 & 614.0 \\
$\quad$ Memoranda: & & & & & & & \\
Current account balance & 209.6 & 296.8 & 413.4 & 385.7 & 473.9 & 530.7 & 665.9 \\
Statistical discrepancy & 134.6 & 65.1 & -62.8 & -29.3 & -95.0 & -12.0 & 51.9 \\
\hline
\end{tabular}

Source: Bureau of Economic Analysis, U.S. International Transactions, table 1.

a. Items may not sum to totals because of rounding.

b. Excluding U.S. Treasury securities.

say that it served to finance the $\$ 248.5$ billion in foreign direct investment acquisitions by U.S. firms. In fact, as my figure 1 shows, although the share of official flows into the United States has recently increased dramatically, from about zero to 25 percent of foreign-owned assets in the United States, this follows just as dramatic a collapse, from 25 percent to -5 percent between 1996 and 1998.

Figure 1 highlights that official purchases represent-except for the few years of the equity bubble - a relatively stable share of gross liability flows. As a rough estimate, foreign official assets provide at most only a quarter of the total capital inflows into the United States.

CURRENT ACCOUNT REVERSALS AND ASSET SUBSTITUTION. The portfolio balance model developed in the paper predicts large but delayed current 
Figure 1. Share of Official Assets in Total Foreign Purchases of U.S. Assets ${ }^{\mathrm{a}}$

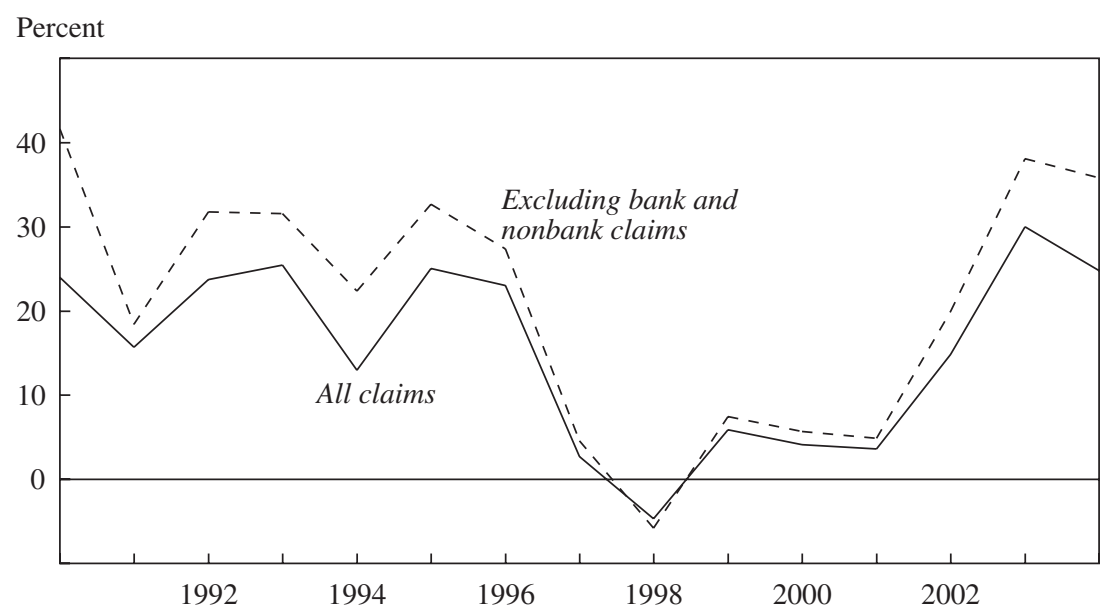

Source: Bureau of Economic Analysis, International Transactions Accounts.

a. Figure reports official purchases as a share of all foreign claims in the United States and as a share of all foreign claims excluding bank and non bank claims. Bank and nonbank asset and liability claims roughly offset each other.

account and exchange rate adjustments. I must admit that I was initially puzzled by the difference between the estimates of this paper and those by Olivier Blanchard, Francesco Giavazzi, and Filipa Sa in this volume. After all, both papers use the same model (in Edwards's paper, equations 1 through 4) and a similar calibration of the model's parameters. Both models emphasize the sort of valuation effects that have received considerable attention recently. ${ }^{4}$ Yet Blanchard, Giavazzi, and Sa predict a gradual adjustment of the current account (and a gradual depreciation of the dollar, cumulating to 54 percent), whereas, as already noted, Edwards predicts that the current account will keep worsening for the next four years before reversing sharply between 2009 and 2012.

The answer lies in the specification of the asset demand side of both models. Whereas Blanchard and his coauthors assume that investors' demand for assets depends upon the expected excess return (the expected rate of dollar depreciation when local currency returns are constant and equal), Edwards assumes that the portfolio shares are exogenous. This is an extreme

4. See Gourinchas and Rey (2005) and Lane and Milesi-Ferretti (2004b). 
assumption: it implies that there is no substitution between domestic and foreign assets, regardless of their relative returns.

Edwards assumes that the degree of home bias in investment decreases exogenously between 2004 and 2010. Crucially, it decreases more for foreign investors (the share of U.S. assets in foreign portfolios increases from 0.3 to 0.4 ) than for U.S. investors (the share of foreign assets in U.S. portfolio increases from 0.27 to 0.29 ). Abstracting from the short-term dynamics represented by equation 10, this decline in relative home bias is what sustains the increase in current account deficits for the next four years (top left panel of Edwards's figure 5) and the continued appreciation of the dollar over the same period (bottom right panel of figure 5).

But consider what happens when foreigners stop increasing the share of U.S. assets in their portfolios. At that point the drying up in foreign financing requires a drastic current account reversal, which can only be triggered by a real dollar depreciation. Hence the predictions of the current account reversal in terms of timing and magnitude come mostly from the assumptions about the path of relative asset shares. The sharp dollar depreciation that occurs when the adjustment begins delivers crushingly low returns to foreigners on their U.S. investment. They lose 22 percent in three years if local currency returns are equal and constant. One would expect that, faced with such negative excess returns, investors would demand less U.S. assets today. But a lower demand for U.S. assets today would precipitate the adjustment in the exchange rate and the current account. This indicates that the assumption of exogenous portfolio shares, although useful to calibrate and simplify the model, is eventually too extreme.

Besides the assumptions on portfolio shares, the assumption of a common growth rate in the United States and the rest of the world matters also. ${ }^{5}$ Consider, for instance, what would happen if the rest of the world is expected to grow faster than the United States. Given stable portfolio shares, foreigners will want to purchase more U.S. assets as they grow richer. Hence the supply of foreign capital will not collapse abruptly.

5. This is especially important when looking at the steady state of the model. In the benchmark calibration, while the trade deficit stabilizes, the dollar keeps depreciating in real terms. What is happening is a consequence of the Houthakker-Magee paradox. If the income elasticity of imports exceeds that of exports, the real depreciation must occur along a balanced growth path with common growth rates at home and abroad and a stable ratio of the trade balance to GDP. It is possible to have a stable real exchange rate if the rest of the world grows faster than the United States (Krugman's 45-degree rule; Krugman, 1989). 
CURRENT ACCOUNT REVERSALS AND GROWTH. The last part of the paper emphasizes that a current account reversal is likely to trigger a growth slowdown in the United States. This section presents a rich set of empirical results. This is an area where Edwards has made numerous important contributions, and I will limit myself to two brief observations. The first is that his projected real depreciation of the dollar does not allow for the possibility of a U.S. growth slowdown. Yet it is possible that a decline in output growth would improve the current account, and as imports drop with domestic income, the residual decline in the real exchange rate should be comparatively smaller than in the absence of a slowdown.

More important, although I agree with the general conclusion of this section-indeed, it is hard to see how a current account reversal of the size that the paper projects could occur without major disruptions in the U.S. economy-it is important to keep in mind that the U.S. situation is unprecedented in many ways besides the size of the external deficit. In particular, never before in peacetime has the center country of the international monetary system accumulated net liabilities on such a scale. It is reasonable to analyze current account reversals for other economies-most of which are small relative to gross world product - using the small-country theoretical apparatus. It is more questionable to do the same for the United States, as Edwards acknowledges. General equilibrium considerationsalready essential in understanding the source of the current account deficit in the first place-are crucial in understanding the possible rebalancing that needs to occur. World asset and good prices cannot be taken as given.

To conclude, it is the great merit of this paper to offer an ambitious contribution to the debate on the sustainability and ultimate adjustment in U.S. external imbalances. The paper's emphasis on the portfolio allocation problem is also most welcome.

General discussion: Panel members discussed Edwards's model's prediction of a sharp depreciation of the dollar leading to current account reversal and possible crisis. Olivier Blanchard observed that these predictions result from the absence of valuation effects and zero substitutability between domestic and foreign assets in the model. With valuation effects, a smaller depreciation of the dollar would reduce the share of dollar assets in foreign portfolios to the level consistent with foreign investors' preferences. And, with some substitutability between domestic and foreign assets, the depreciation would likely be much more gradual, starting as soon as investors 
anticipated the possibility of a change in portfolio preferences. Indeed, it would already have started. Richard Cooper believed the model's assumption that foreign investors would target a certain share of U.S. assets in their portfolios was too rigid. Although the assumption of a preference shift to more dollar assets can explain the recent accumulation, in the simulations, when the new, preferred portfolio is achieved, the demand for U.S. assets falls abruptly, leading to a crisis. Cooper suggested that a more natural baseline might call for some fraction of rest-of-world saving to be invested in the United States for an extended period, in which case the model would predict a gradual slowdown in demand for U.S. assets and a much softer landing.

Peter Garber observed that Edwards's baseline model does not explain how the rest of the world would absorb $\$ 500$ billion of added saving that would arise from a reversal in the U.S. current account equal to 4 percent of U.S. GDP. He conjectured that the added saving would feed back into foreign investors' behavior, possibly changing the model's predictions in a meaningful way. Gian Maria Milesi-Ferretti said he found it difficult to judge how far the present, decade-long trend toward greater global diversification of portfolios would go or how it might end. The world may be transitioning to a new steady state, but we have little guidance about where that new steady state will be. This implies that the history of current account reversals is not a good benchmark for the present U.S. situation, but one cannot rule out the possibility that some shock will lead to a crisis and return investors' behavior to what it was in the 1990s.

Barry Eichengreen questioned the robustness of the paper's empirical analysis, comparing it to a similar recent analysis by Hilary Croke, Steven Kamin, and Sylvain Leduc. Their sample includes more industrialized countries and a less restrictive definition of reversal, which leads them to predict sizable current account reversals in some large countries, including France, the United Kingdom, and the United States. Unlike Edwards, however, they do not find large negative output effects associated with reversals, possibly indicating that large countries are able to adjust more smoothly. Sebastian Edwards replied that the differences between his results and those of Croke, Kamin, and Leduc arise from the very mild episodes of exchange rate adjustment that qualify as reversals in their analysis. He found it unsurprising that such gradual adjustments are not disruptive.

Hélène Rey professed puzzlement at Edwards's finding that a sudden stop or reversal of capital inflows has more pronounced effects the higher the 
degree of trade openness. Theory, as embodied in the model by Obstfeld and Rogoff in this volume, holds that a more closed economy requires a larger relative price adjustment, which suggests that the disruption to the economy will be more substantial. Believing there might be an omitted-variable bias in Edwards's results, she suggested including the degree of liability dollarization, which has been a robust explanatory variable in the sudden stop literature, as an independent variable. Edwards agreed that his results were surprising, but he added that, in the sudden stop literature, liability dollarization plays no role in the impact of a sudden stop or reversal, but only on the probability of their happening. Milesi-Ferretti conjectured that the reason the empirical analysis found current account reversals not to be associated with large exchange rate swings is that changes in the terms of trade are often associated with current account reversals. As examples he noted that some countries in the sample, such as Norway and New Zealand, have highly volatile terms of trade. If the price of their exports doubles, their current account balances improve without a weakening of their currencies.

Several panelists stressed the importance of valuation effects in preventing the U.S. net debt position from increasing substantially in recent years. Cooper pointed out that, in 2003, the U.S. current account deficit reached $\$ 530$ billion, yet the U.S. net asset position declined by only $\$ 98$ billion. The valuation effects that account for this difference are due both to exchange rate effects and to differing returns on foreign and domestic gross portfolios. Richard Portes observed that the depreciation that contributed to these valuation effects cannot go on forever. Milesi-Ferretti added that, to the extent valuation effects from differences in asset returns hold up the dollar, the trade deficit will grow faster, requiring a larger depreciation eventually. 


\section{References}

Ades, Alberto, and Federico Kaune. 1997. "A New Measure of Current Account Sustainability for Developing Countries.” New York: Goldman Sachs Emerging Markets Economic Research.

Barro, Robert J., and Xavier Sala-i-Martin. 1995. Economic Growth. New York: McGraw-Hill.

Benassy-Quere, Agnes, Pascale Duran-Vigneron, Amina Lahreche-Revil, and Valerie Mignon. 2004. "Burden Sharing and Exchange Rate Misalignments within the Group of Twenty." In Dollar Adjustment: How Far? Against What? edited by C. Fred Bergsten and John Williamson. Washington: Institute for International Economics.

Bergsten, C. Fred, and John Williamson, eds. 2003. Dollar Overvaluation and the World Economy. Special Report 16. Washington: Institute for International Economics (February). 2004. Dollar Adjustment: How Far? Against What? Washington: Institute for International Economics.

Bernanke, Ben S. 2005. "The Global Saving Glut and the U.S. Current Account Deficit." The Sandridge Lecture, Virginia Association of Economics, Richmond, March 10. Available at www.federalreserve.gov/boarddocs/speeches/ 2005/200503102.

Blanchard, Olivier, Francesco Giavazzi, and Filipa Sa. 2005. "The U.S. Current Account and the Dollar." Working Paper 11137. Cambridge, Mass.: National Bureau of Economic Research (February).

Caballero, Ricardo, Emmanuel Farhi, and Mohamad L. Hammour. 2004. "Speculative Growth: Hints from the U.S. Economy." Working Paper 10518. Cambridge, Mass.: National Bureau of Economic Research (May).

Calvo, Guillermo A., Alejandro Izquierdo, and Luis-Fernando Mejia. 2004. "On the Empirics of Sudden Stops: The Relevance of Balance-Sheet Effects." Working Paper 10520. Cambridge, Mass.: National Bureau of Economic Research (May).

Choi, Chi-Young, Nelson Mark, and Donggyu Sul. 2004. "Unbiased Estimation of the Half-Life to PPP Convergence in Panel Data." Working Paper 10614. Cambridge, Mass.: National Bureau of Economic Research (July).

Cooper, Richard. 2004. “America's Current Account Deficit Is Not Only Sustainable, It Is Perfectly Logical Given the World's Hunger for Investment Returns and Dollar Reserves." Financial Times, November 1.

Corden, W. Max. 1994. Economic Policy, Exchange Rates, and the International System. University of Chicago Press.

Croke, Hilary, Steven B. Kamin, and Sylvain Leduc. 2005. "Financial Market Developments and Economic Activity during Current Account Adjustments in Industrial Economies.” International Finance Discussion Paper 827. Washington: Board of Governors of the Federal Reserve System (February). 
Dollar, David. 1992. "Outward-Oriented Developing Economies Really Do Grow More Rapidly: Evidence from 95 LDCs, 1976-1985.” Economic Development and Cultural Change 40, no. 3: 523-44.

Dooley, Michael P., David Folkerts-Landau, and Peter Garber. 2004a. "The Revived Bretton Woods System: The Effects of Periphery Intervention and Reserve Management on Interest Rates and Exchange Rates in Center Countries." Working Paper 10332. Cambridge, Mass.: National Bureau of Economic Research (March). . 2004b. "Direct Investment, Rising Real Wages and the Absorption of Excess Labor in the Periphery." Working Paper 10626. Cambridge, Mass.: National Bureau of Economic Research (July).

Edwards, Sebastian. 1995. Crisis and Reform in Latin America: From Despair to Hope. Oxford University Press for the World Bank.

. 1999. "Crisis Prevention: Lessons from Mexico and East Asia." Working Paper 7233. Cambridge, Mass.: National Bureau of Economic Research (July).

2002. "Does the Current Account Matter?" In Preventing Currency Crises in Emerging Markets, edited by Sebastian Edwards and Jeffrey A. Frankel. University of Chicago Press.

2003. "Debt Relief and the Current Account: An Analysis of the HIPC

Initiative." World Economy 26, no. 4: 513-31.

. 2004. "Thirty Years of Current Account Imbalances, Current Account

Reversals and Sudden Stops." International Monetary Fund Staff Papers 51 (special issue): 1-49 (January).

. Forthcoming. "Capital Controls, Sudden Stops and Current Account

Reversals." In International Capital Flows, edited by Sebastian Edwards. University of Chicago Press.

Edwards, Sebastian, and Eduardo Levy-Yeyati. Forthcoming. "Flexible Exchange Rates as Shock Absorbers." European Economic Review.

Eichengreen, Barry, Andrew K. Rose, and Charles Wyplosz. 1996. "Contagious Currency Crises.” Working Paper 5681. Cambridge, Mass.: National Bureau of Economic Research (July).

Frankel, Jeffrey A., and Eduardo A. Cavallo. 2004. "Does Openness to Trade Make Countries More Vulnerable to Sudden Stops, or Less? Using Gravity to Establish Causality." Working Paper 10957. Cambridge, Mass.: National Bureau of Economic Research (December).

Frankel, Jeffrey A., and Andrew K. Rose. 1996. "Currency Crashes in Emerging Markets: An Empirical Treatment." Journal of International Economics 41, no. 3-4: 351-66.

Freund, Caroline L. 2000. "Current Account Adjustment in Industrialized Countries." International Finance Discussion Paper 692. Washington: Board of Governors of the Federal Reserve System (December). 
Gourinchas, Pierre-Olivier, and Hélène Rey. 2005. "International Financial Adjustment." Working Paper 11155. Cambridge, Mass.: National Bureau of Economic Research (February).

Guidotti, Pablo E., Agustin Villar, and Federico Sturzenegger. 2003. "Aftermaths of Current Account Reversals: Export Growth or Import Compression." Paper presented at the Eighth LACEA Meeting, Puebla, Mexico, October.

Hooper, Peter, Karen Johnson, and Jaime Marquez. 2000. "Trade Elasticities for G-7 Countries." Princeton Studies in International Economics 87. Princeton University.

Kraay, Aart, and Jaume Ventura. 2002. "Current Accounts in the Long and Short Run.” Working Paper 9030. Cambridge, Mass.: National Bureau of Economic Research (June).

Krugman, Paul R. 1989. "Differences in Income Elasticities and Trends in Real Exchange Rates." Working Paper 2761. Cambridge, Mass.: National Bureau of Economic Research.

Lane, Philip R., and Gian Maria Milesi-Ferretti. 2001. "The External Wealth of Nations: Measures of Foreign Assets and Liabilities for Industrial and Developing Countries." Journal of International Economics 55, no. 2: 263-94. 2004a. "International Investment Patterns." Discussion Paper 4499. London: Centre for Economic Policy Research (July). 2004b. "Financial Globalization and Exchange Rates." CEPR Discussion Paper 4745. London: Centre for Economic Policy Research (November).

Mann, Catherine L. 1999. Is the U.S. Trade Deficit Sustainable? Washington: Institute for International Economics.

2003. "How Long the Strong Dollar?" In Dollar Overvaluation and the World Economy, edited by C. Fred Bergsten and John Williamson. Special Report 16. Washington: Institute for International Economics (February).

2004. "The U.S. Current Account, New Economy Services, and Implications for Sustainability." Review of International Economics 12, no. 2 (special issue): 262-76 (May).

Milesi-Ferretti, Gian Maria, and Assaf Razin. 2000. "Current Account Reversals and Currency Crises: Empirical Regularities." In Currency Crises, edited by Paul Krugman. University of Chicago Press.

Mussa, Michael. 2004. "Exchange Rate Adjustments Needed to Reduce Global Payments Imbalance." In Dollar Adjustment: How Far? Against What? edited by C. Fred Bergsten and John Williamson. Washington: Institute for International Economics.

Obstfeld, Maurice, and Kenneth Rogoff. 2000. "Perspectives on OECD Economic Integration: Implications for U.S. Current Account Adjustment." In Global Economic Integration: Opportunities and Challenges. Kansas City, Mo.: Federal Reserve Bank of Kansas City (August). 
2004. "The Unsustainable U.S. Current Account Position Revisited." Working Paper 10869. Cambridge, Mass.: National Bureau of Economic Research (November).

O'Neill, Jim. 2003. "Features of a Dollar Decline.” In Dollar Overvaluation and the World Economy, edited by C. Fred Bergsten and John Williamson. Special Report 16. Washington: Institute for International Economics (February).

O’Neill, Jim, and Jan Hatzius. 2002. "US Balance of Payments: Still Unsustainable." Global Economics Paper 70. New York: Goldman Sachs (March). 2004. "US Balance of Payments: Unsustainable, But...." Global Economics Paper 104. New York: Goldman Sachs (March).

Rajan, Raghuram G. 2005. "Global Current Account Imbalances: Hard Landing or Soft Landing." Speech at the Credit Suisse First Boston Conference, March 15. Available at www.imf.org/external/np/speeches/2005/031505.htm.

Roubini, Nouriel, and Brad Setser. 2004. "The U.S. as a Net Debtor: The Sustainability of the U.S. External Imbalances." Stern School of Business, New York University, and University College, Oxford (August).

Sachs, Jeffrey D., and Andrew Warner. 1995. "Economic Reform and the Process of Global Integration." BPEA, no. 1: 1-95.

Taylor, Alan M. 2002. “A Century of Current Account Dynamics.” Working Paper 8927. Cambridge, Mass.: National Bureau of Economic Research (May).

Tille, Cedric. 2003. "The Impact of Exchange Rate Movements on US Foreign Debt." Current Issues in Economics and Finance 9, no. 1: 1-7 (January).

Wren-Lewis, Simon. 2004. "The Needed Changes in Bilateral Exchange Rates." In Dollar Adjustment: How Far? Against What? edited by C. Fred Bergsten and John Williamson. Washington: Institute for International Economics. 